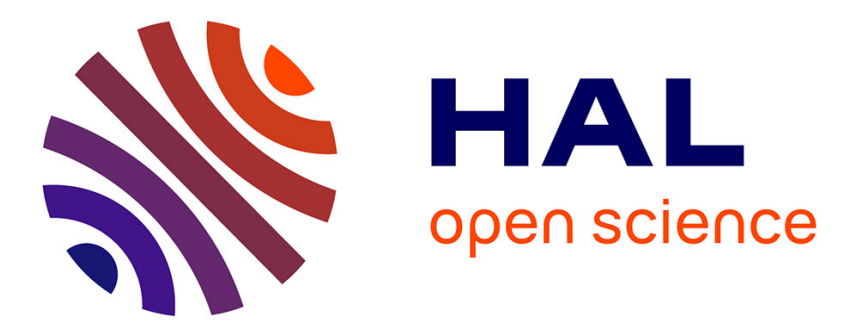

\title{
New material of Palaeoamasia kansui (Embrithopoda, Mammalia) from the Eocene of Turkey and a phylogenetic analysis of Embrithopoda at the species level
}

Ozan Erdal, Pierre-Olivier Antoine, Sevket Sen

\section{To cite this version:}

Ozan Erdal, Pierre-Olivier Antoine, Sevket Sen. New material of Palaeoamasia kansui (Embrithopoda, Mammalia) from the Eocene of Turkey and a phylogenetic analysis of Embrithopoda at the species level. Palaeontology, 2016, 10.1111/pala.12247 . hal-01346066

\section{HAL Id: hal-01346066 https://hal.sorbonne-universite.fr/hal-01346066}

Submitted on 18 Jul 2016

HAL is a multi-disciplinary open access archive for the deposit and dissemination of scientific research documents, whether they are published or not. The documents may come from teaching and research institutions in France or abroad, or from public or private research centers.
L'archive ouverte pluridisciplinaire HAL, est destinée au dépôt et à la diffusion de documents scientifiques de niveau recherche, publiés ou non, émanant des établissements d'enseignement et de recherche français ou étrangers, des laboratoires publics ou privés. 


\title{
NEW REMAINS OF PALAEOAMASIA KANSUI (EMBRITHOPODA, MAMMALIA) \\ FROM THE EOCENE OF TURKEY AND A PHYLOGENETIC ANALYSIS OF EMBRITHOPODA AT THE SPECIES LEVEL
}

\author{
by OZAN ERDAL ${ }^{1}$, PIERRE-OLIVIER ANTOINE ${ }^{2}$ and SEVKET SEN $^{3}$ \\ ${ }^{1}$ Eurasia Institute of Earth Sciences, Istanbul Technical University, 34469 Maslak, Istanbul, \\ Turkey, erdalo@itu.edu.tr \\ ${ }^{2}$ Institut des Sciences de l'Evolution, UMR 5554 CNRS, Université de Montpellier, EPHE, \\ UR 226 IRD, Place Eugène Bataillon, F-34095 Montpellier cedex 5, France, pierre- \\ olivier.antoine@umontpellier.fr \\ ${ }^{3}$ Sorbonne Universités, Centre de recherches sur la Paléobiodiversité et les \\ Paléoenvironnements, UMR 7207 CNRS, UPMC, MNHN, 8 rue Buffon, 75005, Paris, \\ France, sen@mnhn.fr
}

\begin{abstract}
Since the discovery of the megaherbivore Arsinoitherium zitteli Beadnell (early Oligocene of Egypt), the extinct order Embrithopoda has remained an enigmatic group, with disputed affinities among ungulates. In this study, new specimens of Palaeoamasia kansui from the early Palaeogene of Turkey are described and a synthetic dental terminology is proposed for embrithopods. Based on 130 cranial-mandibular and dental characters, the first phylogenetic analysis of embrithopods is carried out in aim to enhance the position of Palaeoamasia within embrithopods. The monophyly of Embrithopoda is confirmed, following the topology [Phenacolophus, [Namatherium, [Arsinoitheriinae, Palaeamasiinae]]]. However, phylogenetic relationships between Eurasian embrithopods (Palaeoamasiinae: Palaeoamasia, Crivadiatherium, and Hypsamasia) remain unresolved. The integration of all
\end{abstract}


embrithopod genera within a cladistic analysis encompassing a wider taxonomic sample (Condylarthra, Afrotheria/Paenungulata, and Laurasiatheria) also supports Embrithopoda as being monophyletic, but questions both the position of Phenacolophus and Namatherium within Embrithopoda. This latter analysis points to palaeobiogeography and the occurrence of a single/two distinct dispersal event(s) for embrithopods between Eurasia and Africa during the early Palaeogene.

Key words: Embrithopoda, Palaeoamasia, Palaeogene, systematics, phylogeny, palaeobiogeography.

SINCE the discovery of Arsinoitherium Beadnell, 1902 in Fayum (Egypt) and its detailed description by Andrews (1906), who provided the general definition of the order Embrithopoda, many other remains were found in Africa, the Arabian Peninsula, and Eurasia (Fig.1). However, these extinct megaherbivores are mostly represented by cranial-dental specimens, except for Arsinoitherium zitteli. Hence, the order is still considered one of the most enigmatic groups within mammals in terms of systematics and phylogenetic relationships. As well, some disagreements endure on their origin, palaeoenvironment or lifestyle and dispersal routes that are paradoxical to palaeogeographic maps (Sen 2013; Sanders et al. 2014 and references therein).

All embrithopods with corresponding localities, time interval and authors are summarised in Table 1 and illustrated in Figure 1 in stratigraphical order.

In the Afro-Arabian fossil record, embrithopods are described under two genera, Arsinoitherium and Namatherium, ranging from the middle Eocene up to the latest Oligocene. The former genus is better documented from dozen localities and only two species are 
considered valid (A. zitteli and A. giganteum) whereas Arsinoitherium andrewsi is accepted as a synonym of A. zitteli (Andrews 1906; Sanders et al. 2004; Al-Sayigh et al. 2008).

Arsinoitherium giganteum is greater than other embrithopods in molar size (Sanders et al. 2004). Namatherium blackcrowense is more primitive than Arsinoitherium based on its upper molar and palatal morphology and it represents the oldest embrithopod in Afro-Arabia (Pickford et al. 2008).

Although fossil finds of embrithopods are more abundant in Afro-Arabia, the oldest described representatives appear so far in Eurasia from the middle-late Eocene of Romania with Crivadiatherium mackennai and C. iliescui (Radulesco et al. 1976; Radulesco \& Sudre 1985; Radulesco \& Samson 1987) and from the early to late Eocene of Turkey with Palaeoamasia kansui (Ozansoy 1966; Sen \& Heintz 1979), Palaeoamasia cf. kansui (A. Gül, unpub. data, 2003) and Hypsamasia seni (Maas et al. 1998; see Sen 2013 for detailed stratigraphic discussion).

Recently, Sanders et al. (2014) recorded remains of a possible new species of Palaeoamasia in the Boyabat Basin (north-central Turkey). These authors claim that it extends the upper limit of Eurasian embrithopods up to Eocene-Oligocene boundary with a robust stratigraphic sampling. Besides, they consider, based on the M3 features, that the Boyabat form is intermediate between P. kansui from Turkey and Namatherium and Arsinoitherium from AfroArabia (Sanders et al. 2014, p.1159).

Among Embrithopoda, Sen \& Heintz (1979) regrouped Crivadiatherium and Palaeoamasia in the new subfamily Palaeoamasiinae in order to distinguish them from the African Arsinoitherium (Arsinoitheriinae), both in the family Arsinoitheriidae Andrews, 1906 (Sen \& Heintz 1979; Radulesco \& Sudre 1985; Radulesco \& Samson 1987; McKenna \& Bell 1997). The last member of that family Namatherium blackcrowense was added by Pickford et al. 
Thereafter, Kaya (1995) elevated Palaeoamasiinae to family rank, Palaeoamasiidae. This statement was also supported by several authors: Maas et al. (1998) with inclusion of Hypsamasia seni; Gheerbrant et al. (2005a), according to their phylogenetic analysis and Sanders et al. (2014) with the recent discovery of the latest Palaeoamasia specimen from the Eocene-Oligocene transition in Turkey.

Phenacolophus fallax Matthew \& Granger 1925 from the late Paleocene - early Eocene of Gashato Formation (Mongolia) has disputed affinities, being considered either as a basal embrithopod (McKenna \& Manning 1977), sister group to them (Gheerbrant et al. 2005a, 2014) or not closely related to them (Sen \& Heintz 1979; Radulesco \& Sudre 1985; Radulesco \& Samson 1987; Court 1992c; Kaya 1995; Koenigswald 2012; Sanders et al. 2014; Mao et al. 2015). For instance, Novacek and Wyss (1986) mentioned a possible close relationship between Phenacolophus and Tethytheria; McKenna \& Bell (1997) regrouped Phenacolophidae (Phenacolophus + Minchenella) and Arsinoitheriidae within Embrithopoda; Sen (2013) considered that 'phenacolophids remain the most likely stem-group for embrithopods, if not for all paenungulates'.

The name Embrithopoda was originally designated to distinguish Arsinoitherium from other ungulates, and originally as a suborder and it is thought to be derived from a hyracoid stock (Andrews 1906, p. xiv). Since then, embrithopods have undergone several systematic revisions and their interordinal relationships remain widely unresolved (see Table 2; Gheerbrant \& Tassy 2009; Sanders et al. 2010; Sen 2013).

Although embrithopods were thought to be endemic to Africa, discoveries of early embrithopods with more primitive features in the 1970s from older Palaeogene Eurasian deposits onward enhanced their possible Eurasian origin (Radulesco et al. 1976; McKenna \& Manning 1977; Sen \& Heintz 1979; Radulesco \& Samson 1985; Gheerbrant et al. 2005b). 
In addition, conflicting ideas about their palaeoenvironment and lifestyle, which would favour our understanding of their dispersals on both sides of Neo-Tethys, remain unresolved (Sen 2013). According to some authors, embrithopods were land-dwellers (Andrews 1906; Thenius 1969; C. Delmer, unpub. data 2005; Clementz et al. 2008) or they had a semi-aquatic lifestyle for others (Moustapha 1955; Sen \& Heintz 1979; Court 1993; Rose 2006; Hutchinson et al. 2011). However, Sanders et al. (2004) refused rigorously that embrithopods were semiaquatic considering their ability to disperse to highland terrestrial habitats in Ethiopia. In this paper, we describe a new material of Palaeoamasia kansui from the type locality EskiÇeltek (Amasya, Turkey) and propose a coherent and neat dental terminology for all embrithopods (Fig. 2). We also provide the first exhaustive phylogenetic analysis of embrithopods at the species level with a relatively restricted taxonomic sample in order to improve the position of Palaeoamasia within Embrithopoda, based on cranial, mandibular, and dental characters. In addition, we tentatively reinvestigate the supraordinal phylogenetic position of embrithopods among fossil ungulates. For this, we include all embrithopod species to the data matrix of Tabuce et al. (2007) wherein Arsinoitherium zitteli was the only representative of the order. Finally, we question their origin and dispersal modalities in the light of phylogenetic results obtained.

\section{MATERIAL AND METHODS}

\section{Comparison material}

The new material of Palaeoamasia kansui from Eski-Çeltek (Amasya, Turkey) is directly compared to published material of the same species by Ozansoy (1966, fig. 3-4) and Sen \& Heintz (1979) (MNHN-EÇ-1, left mandibular fragment bearing highly damaged trigonid of m1, m2 and m3; MNHN-EÇ-4, palate fragment bearing left P3-M3 and right P4-M1; MTA1770, right maxillary with P4-M2; MTA-1771, left mandibular with m1-m3; MNHN-EÇ-3, 
left mandibular with m2-m3 of which crowns are broken; MNHN-EÇ-2, left mandibular with m3) stored in Muséum National d'Histoire Naturelle, Paris (France) and Mineral Research and Exploration Institute, Ankara (Turkey). We followed the descriptions of Kaya (1995), A. Gül, unpub. data (2003) and Sanders et al. (2014) for the material of Palaeoamasia stored in Museum of Natural History of Ege University (Turkey), Ankara University (Turkey) and University of Michigan, respectively.

The new material is also compared to casts of (1) Hypsamasia seni Maas, Thewissen \& Kappelman, 1998 from the late Paleocene - early Eocene of Haymana-Polatlı Basin, Turkey (right P2-P3, fragments of right P4 and M1, central portion of left M1, mesial half of M2; fragment of M3 in eruption; Maas et al. 1998); (2) Crivadiatherium mackennai Radulesco, Iliesco \& Iliesco, 1976 from the middle Eocene of Hateg depression, Romania (isolated left p4-m1; Radulesco et al. 1976); (3) Criviadiatherium iliescui Radulesco \& Sudre, 1985 from the same locality and age as C. mackennai (right m2-m3, left p2-p4, left m2-m3; Radulesco \& Sudre 1985; Radulesco \& Samson 1987); (4) Arsinoitherium zitteli Beadnell, 1902 from the early Oligocene of Fayum, Egypt (left P2-4 and p2-4; Andrews 1906; Court 1992b).

Based on the descriptions and illustrations available in literature, new material is compared to (4) the skull and complete dentition of Arsinoitherium zitteli (Andrews 1906; Court 1992b, 1992c), (5) M2-M3, p4 and m2-m3 of Arsinoitherium giganteum Sanders, Kappelman \& Rasmussen, 2004 from the late Oligocene of Ethiopia (Sanders et al. 2004), (6) the fragmented skull bearing right P3-M3 and left M1-M3 of Namatherium blackcrowense Pickford, Senut, Morales, Mein \& Sanchez, 2008 from the middle Eocene of Namibia (Pickford et al. 2008) and (7) right maxillary fragment with M2-M3 of the youngest Palaeoamasia from the Eocene-Oligocene transition of Boyabat Basin, Turkey (Sanders et al. 2014). P2-P4 and p2-m3 of a putative embrithopod (sensu McKenna \& Manning 1977) Phenacolophus fallax Matthew \& Granger, 1925 from the late Paleocene - early Eocene of 
Mongolia is also included in this study (Matthew \& Granger 1925; McKenna \& Manning 1977).

The earliest known proboscideans Phosphatherium escuilliei Gheerbrant, Sudre \& Cappetta, 1996 (earliest Eocene of Morocco; Gheerbrant et al. 1996, 1998, 2005a; stem proboscidean sensu Benoit et al. 2016 and Cooper et al. 2014) and Eritherium azzouzorum Gheerbrant, 2009 (late Paleocene of Morocco; Gheerbrant 2009; stem paenungulate sensu Cooper et al. 2014), and a hyracoid, Seggeurius amourensis Crochet, 1986 (early Eocene of El-Kohol, Algeria; Court \& Mahboubi 1993) were added in our cladistic analyses as 'branching group' (sensu Antoine 2002 and Orliac et al. 2010). Arsinoitherium andrewsi Lankester, 1903 is considered as a synonym of $A$. zitteli, the differences between them being due to sexual dimorphism or intraspecific variation (Andrews 1906; Sanders et al. 2004; Al-Sayigh et al. 2008). Three genera of Perissodactyla are chosen for the outgroup, namely Xenicohippus (X. grangeri Bown \& Kihm, 1981; X. craspedotum Cope, 1880; X. osborni Bown \& Kihm, 1981 from the early Eocene of United States), Arenahippus (A. grangeri Kitts, 1956; A. aemulor Gingerich, 1991; A. pernix Marsh, 1876 from the early Eocene of United States) and Radinskya McKenna, Chow, Ting \& Luo, 1989 from the late Paleocene of China.

\section{Methods}

In association with detailed observations on specimens and bibliographical researches, 130 morphological characters (10 cranial-mandibular, 120 dental; see Appendix 1) were coded for 14 terminal taxa and a data matrix was generated using Nexus Data Editor v.0.5.0 software (Page 2001; see Appendix 2). Among characters, 81 were chosen from the literature and either used directly or modified for coding. Each character unused in previous phylogenetic analyses is considered new and mentioned with an asterisk in character listing. Within terminal taxa, Xenicohippus, Arenahippus, and Radinskya constitute the outgroup, Seggeurius amourensis, 
Eritherium azzouzorum, Phosphatherium escuilliei, and Phenacolophus fallax form the 'branching group', and seven undisputable embrithopod taxa form the in-group. Cladistic analyses are fulfilled via PAUP 3.1.1 (Swofford 1993) and Winclada v.1.00.08 (Nixon 1999) softwares.

A new and neat dental terminology is proposed and illustrated in Figure 2 for upper/lower premolars and molars of embrithopods by combining descriptions in previous works of McKenna \& Manning (1977), Sen \& Heintz (1979), Iliescu \& Sudre (1985), Court (1992b), Maas et al. (1998), Sanders et al. (2004), and Pickford et al. (2008).

\section{Abbreviations}

Institutional abbreviations. ITU, Istanbul Technical University (Turkey); MNHI, Museum of Natural History of Ege University, Izmir (Turkey); MNHN, Muséum National d'Histoire Naturelle, Paris (France); MTA, Mineral Research and Exploration Institute, Ankara (Turkey); UM2, Université Montpellier 2 (France); ISEM, Institut des Sciences de l'Evolution de Montpellier (France).

Anatomical abbreviations. L, length (mesio-distal); mes. W, mesial width; dis. W, distal width. Upper/lower teeth are mentioned in capital/lower-case letters, respectively: I/i, incisor; C/c, canine; P/p, premolar; M/m, molar; D/d, deciduous tooth.

\section{SYSTEMATIC PALAEONTOLOGY}

The supraspecific systematic here below follows the results of the current phylogenetic analyses. 
Unranked clade PAENUNGULATA Simpson, 1945

Order EMBRITHOPODA Andrews, 1906

Family ARSINOITHERIIDAE Andrews, 1904

Subfamily PALAEOAMASIINAE Sen \& Heintz, 1979

Genus PALAEOAMASIA Ozansoy, 1966

Type species. Palaeoamasia kansui Ozansoy, 1966; the only species of the genus from the type locality, Eocene lignites of Eski-Çeltek, Amasya, Turkey.

Palaeoamasia kansui Ozansoy, 1966

(Fig. 3)

Type material. MNHN-EÇ-1, a left mandibular fragment bearing $\mathrm{m} 1$ with highly damaged trigonid, better preserved m2 and m3 which is assigned as holotype by Sen \& Heintz 1979. Remarks. The m 3 of the holotype lacks the talonid today but it was illustrated by Ozansoy (1966, figs 3-4).

New material. From the type locality, fragment of palate with left P2-P3 (ITU-EÇ-8); right P4-M2 (ITU-EÇ-7); isolated M3 (MNHN-EÇ-6); mandibular fragment with left p2-m1 (ITU-EÇ-9); mandibular fragment with right p4-m1 (MNHN-EÇ-5) (Fig. 3C-L).

Occurrence. Between the late Paleocene and the Eocene-Oligocene transition in Turkey for the genus Palaeoamasia (Ozansoy 1966; Sen \& Heintz 1979; Kazanci \& Gökten 1986; Kaya 1995; Koc \& Türkmen 2002; Ladevèze et al. 2010; Métais et al. 2012; Sanders et al. 2014). 


\section{DESCRIPTIONS}

The dentition of the new material of Palaeoamasia kansui is mesodont with cusps, lophs and lophids are broad and transversally arranged. The enamel is corrugated and moderately thick (1.6 mm). See Figure 2 for dental terminology and Table 3 for dental measurements.

\section{Upper dentition}

Upper premolars. Lack of wear on the mesial side of $\mathrm{P} 2$ might indicate the presence of a diastema between P1 and P2 (as in the lower dentition) or the absence of P1. P2-P4 have at least three roots. The size of premolars increases from P2 to P4. The occlusal outline of P2 is triangular while $\mathrm{P} 3$ and $\mathrm{P} 4$ are squarish. Hence, the preprotocrista of $\mathrm{P} 2$ is more distolingually slanting and the protocone has a much more backward position. Premolars are tribosphenic with a strong ectoloph. The hypocone is absent on all premolars although P3 and P4 have an entoloph formed by the postprotocrista (sensu Court 1992b). The tooth wear is more pronounced distally. The paracone is higher than the other cusps on P2 and P3. On the other hand, the apex of the crown on P4 is located in the middle of the ectoloph. The protocone on $\mathrm{P} 2$ is lower than the paracone, which is less clear on P3-P4. The preprotocrista is interrupted on the lingual base of the paracone on all premolars and it represents the mesial end of the mesio-distal valley, which is followed up to the distal cingulum. This valley (less pronounced on P2) divides P3-P4 into labial and lingual lophs. In mesial view on P2 and P3, the mesial cingulum is sinuous and gets lower at the level of incomplete junction between the preprotocrista and the paracone, which is not the case on P4.

On P2 (ITU-EÇ-8), the mesial cingulum continues distolingually, parallel to the preprotocrista and it disappears on the lingual face of protocone (Fig. 3C). In occlusal view, this cingulum seems to be weak and very close to the mesial wall. At the connection between the parastyle 
and the mesial cingulum, the wall is lightly deflected. The parastyle is individualised by a small groove in front of the paracone. The labial wall is weakly convex mesio-distally. The distal cingulum was probably continuous (one available P2, this part is overlapped by P3). On P3 (ITU-EÇ-8), the mesial cingulum merging from the parastyle is stronger and less sinuous than that of P2 (Fig. 3C). It forms a fossette on the mesio-lingual side of the protocone, which is different from P2. A subvertical and quite deep mesio-labial fossette can be observed at the mesio-lingual junction between the parastyle and paracone. It is much more distinct than on P2. At the disto-lingual angle, the distal cingulum is strong and labio-distally oriented. It is fused with the postprotocrista and continues bucally to form the distal wall. P4 (ITU-EÇ-7) is like an enlarged version of P3 (Fig. 3E). However, in occlusal view, it is more developed labiolingually compared to P3, although it does not show a trend to molarization. The parastyle and metacone are fully joined to the paracone to form a strong ectoloph. The parastyle is mesio-labially elongated and reinforces the depth of the labial groove. Finally, the labial wall is slightly more undulated than on the more anterior premolars. The mesial cingulum connects with the parastyle, and it is more robust and stronger than on P3, particularly at the mesio-lingual angle (mesio-lingual fossette).

Upper molars. Each molar has four roots and is bilophodont: The paracone is fused with the parastyle forming a protoloph, and the metacone is fused with the metastyle forming a metaloph. The protocone and hypocone are isolated from the other cusps on unworn teeth. The ectoloph is absent on all molars. M1 is much smaller than M2 and M3 (Table 3). M3 is slightly larger than M2 although both have a metaloph similar in size because of distal narrowing of M3. In occlusal view, the lophs are oblique mesiolabially. In labial view, the lophs are inclined mesially from the basis towards the apex. In relation to occlusal wear, the distal wall of each loph is much higher than the mesial walls. In occlusal and labial view, the 
mesial loph is thicker than the distal one on M2 and especially remarkable on M3. On M1, high wear degree makes it difficult to observe. Due to tooth wear, the postprotocrista appears to run in a distolabial direction. The mesial and distal cingulums are strong. The labial cingulum is absent and the lingual cingulum is poorly developed, interrupted on the lingual face of each cusps. On M2 and M3, a crista obliqua ('centrocrista' sensu Maas et al. 1998; 'postparacrista' sensu Court 1992b; 'premesostylecrista' sensu Pickford et al. 2008; we follow in this study the term "postparacrista" for upper molars) links the middle of distal face of the protoloph to one third of the labial side of mesostyle. This crista separates the strong lingual groove from the labial groove.

M1 (ITU-EÇ-7) is partially damaged and has a very advanced wear level (Fig. 3E). The postprotocrista is very large and reaches the metaloph. A short cingulum leads to the hypocone (shattered) and disappears on the distal wall basis of the protocone. The metastyle is preserved despite of strong wear, just as a relic of the cingulum on the mesiolingual angle. On M2 (ITU-EÇ-7), the postparacrista connecting the two lophs reaches the occlusal surface of the protoloph (Fig. 3E). This crest is worn revealing a dentine strip. The distolingual angle of the tooth is broken and it is interrupted at the base of the metastyle, preventing observation of the distal cingulum and whether it continues up to the hypocone or not. The lingual cingulum descends from the hypocone and continues toward the flank of the protocone. Following an interruption, this cingulum reappears on the mesiolingual angle of the protocone and becomes labially more marked as a strong mesial cingulum and joins the parastyle. In this configuration it forms a deep fossette.

M3 (MNHN-EÇ-6), less worn than M1 and M2, is well preserved although the parastyle and the apex of the metastyle are damaged (Fig. 3G). It exhibits the same features as M2, though the M3 is distally narrower. A strong and broad mesial cingulum is present between the lingual edge of the protocone and parastyle. On its lingual third, this cingulum becomes 
broader with wear. The boundary of a concave valley is marked by this cingulum and the mesial wall of the protocone. The lingual cingulum is continuous between the base of the fold of the protocone and mesiolingual side of the hypocone. On the distal side of the tooth, a strong postmetacrista joins the thick distal cingulum. The latter surrounds the distolingual angle, reaches the lingual side of hypocone, and is buccally interrupted at the level of the distal fold of the mesostyle. It forms also a deep distolingual fossette.

\section{Mandible}

The left mandible (ITU-EÇ-9; Fig. 2H-J) bears a p2-m1 series and two distinct alveoli in front of $\mathrm{p} 2$, which corresponds respectively to a strong canine and to a one-rooted $\mathrm{p} 1$. These alveoli are separate from each other by a diastema. The canine alveolus is well developed, protruding and transversely oblate (approximate length and width are $14.8 \mathrm{~mm}$ and $10.7 \mathrm{~mm}$, respectively). The canine was probably extending at least until the level of mesial root of $\mathrm{p} 2$. The distal edge of the canine alveolus is also separate by a $10 \mathrm{~mm}$-long diastema from the alveolus of p1. A circular alveolus (width $4.3 \mathrm{~mm}$; depth $6 \mathrm{~mm}$ ) situated at $8.5 \mathrm{~mm}$ mesial to $\mathrm{p} 2$ root proves unquestionably the presence of a $\mathrm{p} 1$.

The mandibular symphysis, broken at its rostral part (no incisor alveolus is preserved), displays the same obliquity as the canine. The distoventral edge reaches the anterior root of p3. In occlusal view, the inter-mandibular angle is very narrow $\left(c .15^{\circ}\right)$. There are two depressions, round and superficial, on the buccal side of the mandible: one below the limit of p2-p3 and the second straight below the distal lophid of p3. They are bite marks from a predator/scavenger. The mental foramen and accessory foramina are not preserved.

\section{Lower dentition}


Lower cheek teeth. ITU-EÇ-9 preserves a p2-m1 series, with a highly worn m1, and MNHNEÇ-5 (Fig. 3K-L) preserves p4-m1, with a broken talonid of p4. All preserved cheek teeth display unilateral hypsodonty (sensu Radulesco et al. 1976). The labiolingual width of teeth and the molarization level increase from p2 to m1 ('série oblongue' sensu Radulesco \& Sudre 1985). p3 and $\mathrm{p} 4$ are molarized. Due to wear, the trigonid of p2-p3 appears to be greater in dimension and much higher than the talonid in lateral view. On $\mathrm{m} 1$, the trigonid and talonid are equally developed. Premolars and molars are two-rooted.

Lower premolars. The cristid oblique links the hypolophid to the protolophid and is centered labio-lingually on $\mathrm{p} 3-\mathrm{p} 4$. It becomes more slanting from $\mathrm{p} 2$ to $\mathrm{p} 4$, with the labiolingual widening of the corresponding teeth. The labial groove arises from the distal part of the crown, just above the distal root; it slants mesiodorsally and reaches the distal side of the metaconid. The width and the depth of that groove increase from $\mathrm{p} 2$ to $\mathrm{p} 4$, thus, it determines a W-shape in occlusal view, formed by the junction of protolophid, cristid oblique and hypolophid; this W-pattern of the occlusal surface accentuates from $\mathrm{p} 2$ to $\mathrm{p} 4$. Wear facets are labio-disto-ventrally oriented on premolars. The degree of wear increases from $\mathrm{p} 2$ to $\mathrm{p} 4$. The lingual or labial cingulids are absent on premolars. On the lingual side, the absolute height of the metaconid increases from $\mathrm{p} 2$ to $\mathrm{p} 4$, until it exceeds the paraconid level on p4 (ITU-EÇ-9). The mesiolabial side of trigonid is convex and occupies a wider place than the talonid. The $\mathrm{p} 2$ is the smallest tooth of the series (Table 3 ). The cusps are aligned mesiodistally contrary to other premolars. The protruded paraconid is isolated by a faint labial depression and a small but well-defined distolingual groove. At an advanced stage of wear, it would have formed a paralophid. The mesostylid rises at the basis of protoconid, slopes down distolingually and reaches the metaconid, thus it determines a small and narrow almond-shaped fossettid. No entoconid is visible on p2 (absence or disappearance due to wear occurred by 
contact with paralophid of p3). However, a small distolingual fossettid forms a superficial depression, which is homologous to the valley of the talonid on $\mathrm{p} 3-\mathrm{p} 4$. On $\mathrm{p} 2$, the protoconid is much higher than the metaconid, contrary to what occurs on $\mathrm{p} 3$ and $\mathrm{p} 4$.

On p3, the occlusal outline is more sinuous. The protolophid connects the protoconid to the metaconid. The paraconid is slightly connected to the protoconid by a paralophid that is oriented labiodistally. The metaconid and paraconid have equivalent height whereas the protoconid, entoconid and hypoconid are much lower. The lophid that connects the hypoconid to the entoconid (hypolophid) is projected over by the paralophid of $\mathrm{p} 4$. The mesiolingual fossettid is as strong as on $\mathrm{p} 2$; the distolingual fossettid is much more developed compared with $\mathrm{p} 2$. The entoconid forms a notch by its ventrolingual elongation (lingual groove of angular talonid in occlusal view).

The p4 (ITU-EÇ-9) has clearly individualised cusps, foreshadowing the morphology of molars. The paralophid is oriented mesially (Fig. $3 \mathrm{H}$ ). The mesiolingual fossettid is wider and deeper as compared to the previous premolars. As in the molars, the metaconid is very spread lingually, pointed mesiodistally and inclined mesiodorsally in lingual view. The distolingual fossettid is semi-circular, wide and deep. The mesiolabial side of the protoconid is faintly depressed. In lingual view, the distal walls of the metaconid and the mesial wall of the entoconid display a symmetric ' $V$ ' shape, whereas in occlusal view it designs a wide ' $U$ '. The length of the talonid is similar to that of the trigonid in occlusal view. The $\mathrm{p} 4$ on the specimen MNHN-EÇ-5, although less worn, perfectly matches that of ITU-EÇ-9 (Fig. 3K). The labial wall of the protoconid is much convex and depressed on its mesiolabial side. Contrary to ITUEÇ-9, the protoconid is much more elevated than the paraconid and this latter is slightly lower than the metaconid (broken). This observation leads us to deduce that wear decreases the size of the protoconid more than the other cusps. A narrow postprotocristid continues vertically until the middle of the distal side of trigonid, where it joins the rest of the cristid oblique. 
Lower molars. The m1 (ITU-EÇ-9) is distally broken (talonid), highly worn, and it provides less information than the $\mathrm{m} 1$ of the specimen MNHN-EÇ-5. This latter specimen is well preserved except for the slightly damaged entoconid and distal cingulid. The trigonid and talonid are equivalent in size. The labial groove, relatively parallel to the mesial and distal lophids, is situated on the middle of the roots in dorsoventral axis. This groove is mesiodorsally oblique in labial view. The mesial cingulid is continuous. The distal cingulid is restricted on the distal wall and rises labiolingually, parallel to the neck (cervix dentis). Unilateral hypsodonty of the crown is salient. A very narrow paralophid is oriented labiolingually. The metaconid is well defined on the lingual side and, together with the metalophid, it surrounds a small superficial mesial fossettid. The cristid oblique rises distally to the metaconid and continues distolabially towards the middle of the hypolophid. The enamel wear facets are distinguishable on the distal side of the lophids, and are labiolingually elongated and nearly vertical. The lingual groove is distolingually oriented in occlusal view and ' $\mathrm{V}$ ' shaped in lingual view. The metaconid, stronger than entoconid in lingual view, is slightly depressed on the mesiolingual side.

\section{COMPARISON AND DISCUSSION}

The dental terminology is illustrated in Figure 2, dental measurements of the new material of P. kansui in addition to Hypsamasia and Crivadiatherium, are given in Table 3 and mean size values distribution of studied taxa in length/width diagrams are available in Figure 4. Mean values are in Appendix 3.

Remark. Gheerbrant et al. (2005a) consider the upper molar lophs not as 'real' lophs. We follow the definition of Court (1992b) in considering the upper molar lophs as derived from a 
hyper-dilambdodonty on which labial cusps immigrate lingually with the postparacrista sensu Court (1992b) (ectoloph sensu Gheerbrant et al. 2005; centrocrista sensu Maas et al. 1998) and with the postmetacrista. Therefore, the lophs of embrithopod cheek teeth are named here as 'pseudolophs' and even the anterior pseudolophs on upper molars are formed with labial migration of paracone and thus, should be named as paraloph, we use the term protoloph to avoid any nomenclature conflict.

\section{Comparison with Palaeoamasia kansui}

The large majority of morphological features studied here are identical to those of the holotype and of other specimens of Palaeoamasia kansui described by Sen \& Heintz (1979): presence of an entoloph on $\mathrm{P} 3-\mathrm{P} 4$, parastyle very distinct and more labially located in comparison to the rest of the ectoloph, and the presence of a strong mesial cingulum and of a preprotocrista having an equivalent length to postprotocrista on P4. Also, on upper molars, the mesial cingulum is reduced, the presence of 'pseudolophs' coincides with the lingual migration of labial cusps ('hyper-dilambdodonty' sensu Court 1992), the postparacrista is very distinct, the lophs are mesio-ventrally inclined, the postparacrista and postmetacrista are present on the distal wall of pseudolophs.

Molarization of p4 is remarkable. Lower premolars lack cingulids, their lophids are separated by an oblique labial groove and the lingual fossettid of the talonid is larger and deeper than the one on the trigonid. Thus, attribution of the new material to P. kansui is well supported. A few rare differences observed between the new specimens and those previously described by Sen \& Heintz (1979) are mainly due to different wear stages and on individual variation. For instance, the teeth display dimensions comparable or slightly smaller than the previously described material of P. kansui (Fig. 4A and Appendix 3; Sen \& Heintz 1979; Kaya 1995; A. Gül, unpub. data, 2003; Sanders et al. 2014). P4 of ITU-EÇ-7 (Fig. 3E) displays a large 
mesio-distal valley that prevents a connection between paracone and preprotocrista (fused on hypodigm). Labio-lingual width of M1 (ITU-EÇ-7) is greater than P4 while those dimensions are similar on MNHN-EÇ-4 (Sen \& Heintz 1979).

On M2, the labial groove is shallower than other P. kansui, the crista oblique joins the protoloph, the surface of the lophs is wider and the protocone is fused to the protoloph. On M3 (MNHN-EÇ-6; Fig. 3G), the crista oblique and postmetacrista are stronger, the protocone is completely integrated into the protoloph and the postprotocrista is more distinct. The distal cingulum on new specimens connects to the mesostyle fold and the mesial cingulum does not join the lingual cingulum (interruption at lingual level of protocone). The p4 of ITU-EÇ-9

(Fig. $3 \mathrm{H}$ ) differs from other specimens by a larger trigonid than talonid in size (Sen \& Heintz 1979, plate 3).

\section{Comparison with a younger Palaeoamasia from Boyabat}

In a recently published paper of Sanders et al. (2014), new Palaeoamasia remains are reported from the Cemalettin Formation of Boyabat Basin (Turkey). So far, they represent the youngest specimens referable to Palaeoamasia (and to an embrithopod outside of AfroArabia, in general). As these authors, we agree on highly similar occlusal features of the only available material, M2-M3 (BOY-2) and ?incisor (BOY-1). Also, measurement ranges are very close, especially with that of $P$. kansui specimens from the type locality Eski-Çeltek (Amasya, Turkey; Fig.4A and Appendix 3). However, the specimen BOY-2 is considered as documenting an unnamed new species of Palaeoamasia, depending on four M3 features, intermediate between those of P. kansui on the one hand and those of Namatherium and Arsinoitherium on the other hand (Sanders et al. 2014, p.1159).

Comparison with Hypsamasia seni 
Upper premolars and molars of $H$. seni (only known teeth) are 15-30\% larger in size (Table 3, Fig. 4) than the ones of new specimens from Eski-Çeltek (P. kansui). P2 of P. kansui differs from those in H. seni in some features, such as: preprotocrista is not curved, the parastyle is smaller and much closer to paracone, the parastylar cingulum (mesial) is less individualised and has a rather triangular shape. The mesio-distal valley seems narrower in premolars of $P$. kansui, the ectoloph is larger and the labial wall is not undulated. On P3, P. kansui differs from $H$. seni in the lack of a paraconule, the presence of a shallower depression between the paracone and mesial wall of the parastyle and also by the lack of superficial labial groove at the level of the metacone. The preprotocrista and postprotocrista of P3-4 of P. kansui have the same length whereas the preprotocrista is longer on H. seni. Upper molars of P. kansui possess a lingual cingulum as well as a robust postparacrista on the distal wall of the protoloph in M2. The latter seems to be greater with a fold labio-ventrally oriented.

\section{Comparison with Crivadiatherium mackennai and C. iliescui}

\section{Both Crivadiatherium species are known only by lower dentition. The premolar of}

\section{Crivadiatherium iliescui which is described as a p1 by Radulesco \& Sudre (1985) and}

Radulesco \& Samson (1987) is considered in this study as a p2, in agreement with Sen (2013) at least for three reasons; (1) the occlusal wear stage seems to be higher for a p1 especially in comparison with p3, (2) despite of the broken small distal part of that tooth, the distal facet at apical level of the entoconid perfectly contacts the mesial facet of the paralophid on $\mathrm{p} 3$, and (3) the mesio-distally increasing size of teeth, i.e. from $\mathrm{p} 2$ to $\mathrm{p} 4$, as observed in other embrithopod species, such as Palaeoamasia kansui. Thus, it is possible to compare the p4-m1 series of P. kansui with that of C. mackennai and the p2-m3 series with that of C. iliescui. Lower premolars of P. kansui (ITU-EÇ-9, Fig. 3H) are distinguished from those of Crivadiatherium by their noticeably smaller size (Table 3, Fig. 4B and Appendix 3) and much 
lower crown, by the W-shape of lophids, by the absence of labial and lingual continuous cingulids, and by less elongated trigonids and talonids. In labial view, the labial groove is slanting mesio-lingually (vertical in Crivadiatherium). Cusps of p2 are mesio-distally aligned and individualised in P. kansui while in C. iliescui they are separate both mesio-distally and labio-lingually. In the latter, p2 is buccally shifted on the dental series, which probably indicates a post-mortem deformation. The $\mathrm{p} 3$ of $P$. kansui has mesio-distally flared crista oblique; hypolophid at the entoconid level does not seem to be distally curved as seen in Crivadiatherium iliescui. On p3-p4, the disto-lingual fossa forms an obvious angle in lingual view (V-shaped) as in C. mackennai; this angle is less marked in C. iliescui (U-shaped). The metaconid is more mesio-distally pinched in the p4 of Palaeoamasia. The entoconid and the talonid are lower in height than the metaconid and trigonid, respectively. The $\mathrm{m} 1 \mathrm{of}$ Palaeoamasia differs from that of $C$. mackennai in the complete lack of the labial cingulid. The mesial cingulid is weaker in C. iliescui in which it forms a fossa on the mesio-labial angle. The lingual cingulid is absent in $P$. kansui and in $C$. iliescui but present in $C$. mackennai. The lower molars of $P$. kansui differ from those of Crivadiatherium in having the labial grooves smaller and shallower, a more mesio-distally compressed crista oblique and rather lingually oriented, more transversally oriented lophids, a weaker and more transversely oriented paralophid, a short trigonid, more convex lingual walls of the metaconid and entoconid, an obvious size increase between $\mathrm{m} 1$ and $\mathrm{m} 3$ (less clear in C. iliescui), trigonid and talonid equally developed on $\mathrm{m} 1-\mathrm{m} 2$ (the trigonid is larger than the talonid in Crivadiatherium), an isolated and weakly developed hypoconulid on $\mathrm{m} 3$ (connected to the entoconid by lingual and labial cristids in Crivadiatherium) and distal inclination of the hypoconulid in lingual view.

Comparison with Arabian-African embrithopods 
The most remarkable differences between P. kansui and Arabian-African embrithopods (Arsinoitherium and Namatherium) are in tooth size and degree of hypsodonty. The latter is less pronounced on Palaeoamasia and it becomes more apparent with Namatherium, Arsinoitherium zitteli and A. giganteum in parallel with increasing dimensions, respectively. However, while P3-M1 of Namatherium are overlapping more or less with the size range of Palaeoamasia, M2 and M3 are slightly larger (Fig. 4A). The premolars and molars of Arsinoitherium are much larger than those of Eurasian embrithopods, and that discrepancy greatly increases for A. giganteum, which has teeth larger than in any other taxon (Fig. 4, Appendix 3).

In addition, Pickford et al. (2008) compared M3 of Namatherium blackcrowense with those of P. kansui and Arsinoitherium. They assume that the hypocone would reduce to a lingual cingulum fused with the metaloph together with a lingual migration of labial cusps, which is noticeable when the hypsodonty degree increases from P. kansui towards Arsinoitherium (Pickford et al. 2008, fig. 16A).

Nevertheless, we observe that the hypocone on M3 of $P$. kansui still remains individualised at early wear stages and it is at the same height as the metaloph. There is a trend to fusion between the hypocone and metaloph in more advanced wear stages. Hereby, it would be more parsimonious (a posteriori) to assume that the hypocone on M3 is already fused to the metaloph rather than a reduction into a cingulum, probably due to increase of hypsodonty level without any advanced dental wear occurrence in Arsinoitherium and Namatherium. Finally, in their differential diagnosis, Pickford et al. (2008, p. 477) mention the lack of an 'interloph' crest that serves to distinguish Namatherium from Palaeoamasia. As we discussed earlier for the late Palaeoamasia specimen from Boyabat, according to our observation, this 'premesostylecrista' is homologous to the centrocrista (sensu Maas et al. 1998). 
As to other dental features, $P$. kansui differs from Arsinoitherium and Namatherium

blackcrowense in having a postmetacrista on upper molars and continuous mesial and lingual cingula on M3. P. kansui differs from A. zitteli and N. blackcrowense in having a postprotocrista on P3-P4 and a divided lingual root (unknown in A. giganteum). P. kansui differs from Arsinoitherium by the presence of a distal cingulum on upper molars, mesiodorsally oblique buccal groove on lower premolars (vertical in Arsinoitherium), trigonid much higher than talonid in lateral view on $\mathrm{p} 2-\mathrm{p} 3$ and lower molars (height is similar in Arsinoitherium), molarization of $\mathrm{p} 3$ and p4, presence of a mesial cingulid, high position of distal cingulids and presence of a cristid oblique at a high position in the middle lingual side of trigonid by extending towards the apex of metaconid on lower molars (this cristid oblique is relatively low and it extends towards the metaconid base in Arsinoitherium), and also size increase from $\mathrm{m} 1$ to $\mathrm{m} 3$ (m2 and $\mathrm{m} 3$ have fairly comparable dimensions in Arsinoitherium, see Fig. 4B).

Regarding the lower jaw, P. kansui (Fig. 3H-J) differs from $A$. zitteli in possessing a mandibular symphysis oblique anteriorly to the distal edge, at the premolar level (sub-vertical anterior to a distal edge at the molar level in $\mathrm{A}$. zitteli) and no mandible angular discontinuity between the premolar and molar series. Upper premolars of $P$. kansui have a distal cingulum and roots higher than crowns (unlike the condition in upper premolars of A. zitteli). The P2 has two labial and one lingual roots, a smooth buccal side (two roots with an undulating side in A. zitteli) and a straight crest which involves the preprotocrista and protocone (this crest is more mesio-lingually convex in premolars of $A$. zitteli). The hypocone is absent on P2-P4; in contrast, it is robust in A. zitteli. Concerning upper molars, P. kansui is distinguished by a salient postparacrista (absent in A. zitteli), the presence of a postprotocrista and M2-M3 larger than the rest of the dental series (size progressively increases from P2 to M3 in A. zitteli, Fig. 4A). As regards lower teeth, $P$. kansui has a canine which is probably caniniform and greater 
in size than the incisors (incisiform in $A$. zitteli), a post-canine diastema as well as a diastema between $\mathrm{p} 1$ and $\mathrm{p} 2$ (those diastemas are absent in $\mathrm{A}$. zitteli), a lingually shifted metaconid which forms a notch on $\mathrm{p} 3$ (integrated in the mesio-distal series in A. zitteli), a V-shaped disto-lingual pit (in lingual view) developed more mesio-distally than its mesial homologous on p4 (this fossa is U-shaped and less developed than its mesial homolog in A. zitteli). P. kansui differs from A. giganteum in the zygomatic process position rising at the level of distal loph of M3 (instead of rising at the level of mesial loph in A. giganteum) and by the absence of a buccal cingulid on the lower premolars, but also regarding crown height. Finally, P. kansui can be distinguished from Namatherium blackcrowense in having a less divergent zygomatic arch laterally (very divergent in N. blackcrowense), which begins at the level of the distal loph of M3 (at the level of M2 in Namatherium), a reduced tuber maxillae (large in Namatherium), no lingual or labial cingulae on upper premolars, and a three-rooted P3 (two-rooted in N. blackcrowense). On upper molars, P. kansui is distinguished by features such as the presence of a distolingual cingulum which extends under the hypocone but is not connected to the lingual cingulum (connected in Namatherium), the absence of a labial cingulum and of mesio-ventrally inclined 'pseudolophs' (merged with the occlusal plane in Namatherium) can distinguish P. kansui from N. blackcrowense. Last, only M3 of $N$. blackcrowense lingually outflanks from the dental series due to its greater size. Note that both M2 and M3 display that feature in P. kansui.

\section{Comparison with Phenacolophus}

P. kansui differs from Phenacolophus fallax (Paleocene of Mongolia) in having a zygomatic process rising at the level of the distal loph of M3 (at the level of M2 in Ph. fallax), an oblique orientation of the mandibular symphysis (sub-vertical in Ph. fallax), no molarisation, in possessing a mesial cingulum but no labial cingulum on upper premolars, in having three- 
rooted P2 and P3 (one-rooted P2 and two-rooted P3 in Ph. fallax), and an ectoloph on P2-P3. The upper premolars of $P h$. fallax are smaller and more brachydont in comparison to those of P. kansui. However, upper premolars of Ph. fallax are described by McKenna \& Manning (1977) as 'very simple' and the incomplete preservation of the premolars does not allow ensuring the presence of an ectoloph in that species. Another character that differentiates $P$. kansui from Ph. fallax is the presence of protocones and postprotocrista in the former. However, it should be noted that McKenna \& Manning (1977) had considered the mesial cusps of P3 in Ph. fallax as paracones. We follow that opinion. In addition, P. kansui has a metacone and a paracone equivalent in size in P3 (metacone smaller than paracone in Ph. fallax). Upper molars of $P$. kansui lack a labial cingulum although it is present in Ph. fallax. As for the distal cingulum, it is lingually elongated under the hypocone but without any continuity with the lingual cingulum, whereas in the Mongolian species, this distal cingulum connects to the lingual cingulum. Also, P. kansui differs from Ph. fallax in having a very distinct preparacrista on upper molars (reduced in Ph. fallax). The postparacrista connects the mesostyle and it is lingually migrated towards the paracone and metacone in P. kansui. Consequently, the occlusal view of upper molars displays a ' $W$ ' shape; upper teeth are hyperdilambdodont (sensu Court 1992b). On the other hand, the paracone and the metacone are much closer to the labial side in Ph. fallax, which is true also for the postparacrista even if the latter is completely connected to mesostyle. Therefore, upper molars of $P h$. fallax are considered by Gheerbrant (2009) as being dilambdodont with a selenodont ectoloph. Conules are absent in the upper molars of P. kansui and the hypsodonty is unilateral (sensu Radulesco et al. 1976), whereas in Ph. fallax, those teeth are brachydont. The postmetacrista is reduced in P. kansui (well developed in Ph. fallax) and M2-M3 are greater in size (Fig. 4, Appendix 3) with an outflanking lingual edge on the rest of dental series (only M3 shows those characters, while other teeth increase in size progressively and mesio-distally in Ph. fallax). 
On lower teeth row, P. kansui differs from Ph. fallax by the presence of c-p1 and (d)p1-p2 diastema, a paraconid being in a higher position on occlusal surface (lower in Ph. fallax) as well as by a labial groove mesio-dorsally oblique (vertical in Ph. fallax) and by the absence of a labial cingulid. The 2 of $P$. kansui is two-rooted (one-rooted in Ph. fallax). Molarisation of p3-p4 is marked in P. kansui and absent in Ph. fallax (p3 is triangular; the talonid is very low on $\mathrm{p} 4$ and lower premolars dimensions are remarkably smaller than dimensions of the molars). A hypoconid is present on $\mathrm{p} 3$ (absent in Ph. fallax) and the metaconid of $\mathrm{p} 4$ is lingually isolated in $P$. kansui (integrated to the mesio-distal row in Ph. fallax). The $\mathrm{p} 4$ of $P$. kansui can be distinguished from Ph. fallax by the absence of mesial and distal cingulids, similar height of trigonid and talonid (talonid is much lower in Ph. fallax) and presence of a mesostylid.

Lower molars of $\mathrm{Ph}$. fallax are considered here as having a bunodont-lophodont structure, in contrast to those of P. kansui (as in Sen \& Heintz 1979, contra Gheerbrant et al. 2005a). Ph. fallax differs from P. kansui in having cusps more distinct (not fused in lophids) together with lower and less lophoid crests. The mesial cingulid of lower molars in P. kansui is poorly developed, whereas in Ph. fallax, that cingulid is strong and forms a fossa on the mesio-labial angle. Specimens of Palaeoamasia from Turkey differ also from Ph. fallax by the absence of a labial cingulid and entocristid, a highly reduced postmetacristid (the latter is distinct and more or less convex into metastylid in Ph. fallax), by the presence of a mesostylid and of a paraconid fused to paralophid (paraconid well discriminated in Ph. fallax). The paralophid of $P$. kansui is situated on a short trigonid and noticeably mesio-distally compressed while in $P h$. fallax that seems to be more developed and functional on a more mesio-distally dilated trigonid. The trigonid and talonid of $P$. kansui have a comparable size in $\mathrm{m} 1-\mathrm{m} 2$ in occlusal view, while in Ph. fallax, the talonid, bearing a distal cingulid, is larger than the trigonid. The cristid oblique has a high position in P. kansui (low in Ph. fallax). It reaches nearly the apex of 
the metaconid, while Ph. fallax possesses a cristid oblique mesially elongated towards the half width on the trigonid distal wall and increasingly more mesially oriented from $\mathrm{m} 1$ to $\mathrm{m} 3$. We note that the height of the trigonid is greater in size in comparison to that of the talonid in $P h$. fallax, although this difference is less remarkable in P. kansui.

\section{PHYLOGENETIC RELATIONSHIPS}

Cladistic analyses are performed by using two methods; 'Branch and Bound' in PAUP 3.1 (Swofford 1993) and heuristic search in Winclada 1.00.08 (Nixon 1999), both using unweighted parsimony, based on 130 cranial-mandibular and dental characters (Appendix 1) and 14 terminal taxa (Appendix 2). Xenicohippus, Arenahippus (Perissodactyla) and Radinskya (either closely related to perissodactyls or belonging to phenacodontid "condylarths"; Rose et al. 2014) are considered as outgroups. Also, one hyracoid and two proboscideans from the Paleocene-Eocene are added as terminals into the cladistic analysis as forming a 'branching group' (sensu Antoine 2002 and Orliac et al. 2010).

We obtained in PAUP 3.1.1 ten equally parsimonious phylogenetic trees with a branch length (L) of 237 steps, consistency index $(\mathrm{CI})=0.603$ and retention index $(\mathrm{RI})=0.612$, which coincide only with six distinct topologies, all four other trees depicting alternative synapomorphy distribution. Winclada 1.00 .08 displayed six equally parsimonious topologies with same lengths and indices as in PAUP 3.1.1 ( $\mathrm{L}=237, \mathrm{CI}=0.60 ; \mathrm{RI}=0.61)$. The strict consensus tree is shown in Figure 5. The list of unambiguous apomorphies (synapomorphies and autapomorphies) and their distribution on the nodes of the strict consensus tree are given in Table 4. The complete distribution list of phylogenetic character is provided in Appendix 4. Most parsimonious topologies are not very contradictory since a single polytomy is observed within the in-group, involving embrithopods from Turkey and Romania (node 9:

[Palaeoamasia kansui, Hypsamasia seni, Crivadiatherium iliescui, C. mackennai]). 
Since one of the purposes of this paper is to check phylogenetic position of Palaeoamasia within other embrithopods, more specifically within Palaeoamasiinae following the consensus tree, five alternative topologies restricted to that group obtained by PAUP 3.1.1 are illustrated in Figure 6 and discussed further.

\section{Strict consensus tree and character distributions}

The strict consensus of ten equally parsimonious trees provides a topology with $\mathrm{L}=243$ steps, $\mathrm{CI}=0.588$ and $\mathrm{RI}=0.587$ (Fig. 5). Among 130 characters included into analysis, 20 are not informative: eight autapomorphies are ambiguous (char. 4, 8, 19, 34, 42, 52, 76, 95) and 12 are unambiguous (char. 13, 23, 27, 32, 37, 77, 86, 93, 103, 110, 124, 130). Only 44 synapomorphies are unambiguous, of which 11 are homoplastic $(<\mathrm{RI}=1)$. The node 2 involves all in-group taxa. It is robust according to Bremer indices $[\mathrm{BI}=5]$ (Bremer 1994). The present taxonomic sample allows us to assimilate that node to Paenungulata, as [Embrithopoda, [Hyracoidea, Proboscidea]]. According to some authors, the phylogenetic relationships among living representatives of Paenungulata are [Hyracoidea, [Proboscidea, Sirenia]] (Meredith et al. 2011; Springer et al. 2011). On the other hand, embrithopods are strictly related to Tethytheria (either to Proboscidea or to [Proboscidea + Sirenia]) and not to hyracoids as a result of previous studies (Court 1992c; Gheerbrant et al. 2005b; Tabuce et al. 2008; Gheerbrant \& Tassy 2009). Rose et al. (2014) did not include any embrithopod in their phylogenetic analysis, but the interordinal relationships they recovered within "ungulates" are [[Perissodactyla, Cambaytheriidae], [Phenacodontidae, [Hyracoidea, Proboscidea]]], where the clade Hyracoidea + Proboscidea encompasses Afrotheria.

The basal clade within the in-group (node 5) corresponds to [Embrithopoda + Phenacolophus fallax]. Interestingly, Phenacolophus was considered as an embrithopod by McKenna \& 
Manning (1977) based on one synapomorphy (weakly developed hypoconulid on m3). This hypothesis is far to be in agreement for some authors (Sen \& Heintz, 1979; Radulesco \& Sudre, 1985; Radulesco \& Samson, 1987; Court, 1992c; Kaya 1995; Koenigswald 2012; Sanders et al. 2010, 2014 and Mao et al. 2015) whereas it is supported in the phylogenetic analysis of Gheerbrant et al. $(2005 \mathrm{a} ; 2014)$ while the phylogenetic relationships are not resolved in Gheerbrant (2009). Phenacolophus appears to be related to Tethytheria in Tabuce et al. (2007) as ([Hyracoidea, [Proboscidea, [Anthracobune, [Phenacolophus, Protosiren]]]]), after exclusion of only embrithopod included in their analysis, Arsinoitherium. The strict relationship of $P h$. fallax with embrithopods is here strongly supported by 10 unambiguous synapomorphies and a $\mathrm{BI}=5$, which is in full agreement with the close relationships between Phenacodontidae and Afrotheria recovered by Rose et al. (2014). Node 6 (Embrithopoda) is supported by three unambiguous synapomorphies $(\mathrm{BI}=3)$.

Namatherium blackcrowense, from the Lutetian of Namibia, is sister group (node 6) to Arsinoitheriidae at node 7 which corresponds to the dichotomy between an Arabian-African clade (Arsinoitherium; node 8) and a Eurasian clade (node 9). As to the Eurasian clade, the phylogenetic relationships are unresolved (H. seni, P. kansui, Crivadiatherium; node 9) and the possible reasons are discussed in further.

According to Pickford et al. (2008), Namatherium is closer to Arsinoitherium in terms of dental morphology (despite cranial differences) than to Palaeoamasia and is classified within Arsinoitheriidae to which Eurasian embrithopods also belong ("Eurasian arsinoitheres" sensu Pickford et al. 2008). Here, the (Namatherium + Arsinoitherium) group is paraphyletic although node 7 is weakly supported ([BI=1]; see devoted section). Accordingly, pending new characters or additional remains, likely to change the branching sequence of Namatherium and in order to favour the use of monophyletic suprageneric taxa within embrithopods, node 7 will be considered as anchoring the clade Arsinoitheriidae in which subordinated clades are 
Arsinoitheriinae Andrews, 1904 with (A. zitteli + A. giganteum; node 8) and Palaeoamasiinae

Sen \& Heintz, 1979 with (P. kansui + Hypsamasia seni + Crivadiatherium mackennai $+C$. iliescui; node 9) as two distinct subfamilies.

The subfamily Palaeoamasiinae, represented by a polytomy in the strict consensus tree, consists of five alternative topologies (Fig. 6), in which only the position of $H$. seni is ambiguous. The lack of phylogenetic resolution within Eurasian embrithopods and the occurrence of a polytomy in the strict consensus tree (Fig. 5) is caused by the fact that $P$. kansui is the only species providing information on upper dentition as well as lower and also on mandibular and maxillary fragments. Unfortunately, Crivadiatherium is only known by its lower dentition whereas $H$. seni is represented by few upper teeth only (heavily damaged and incomplete), which prevents any further phylogenetic resolution.

\section{Distribution of synapomorphies on strict consensus tree}

For each node, unambiguous synapomorphies appear by increasing degree of homoplasy (following Antoine 2002). Corresponding character states are shown in square brackets. The complete list of unambiguous apomorphies is available in Table 4; a complete character distribution list (including ambiguous synapomorphies) is given in Appendix 4.

Node 2: Paenungulata Simpson, 1945. The clade Paenungulata $(\mathrm{BI}=5)$ is well supported by twelve unambiguous synapomorphies among which seven are non-homoplastic:

postprotocrista mesio-distally oriented on upper premolars (18[1]); absence of metaconule on P3 (30[1]) and on P4 (39[1]); absence of paraconule on P4 (38[1]); mesostyle distinct on upper molars (54[1]); dilambdodont upper molars (59[1]); lower incisors medium-sized to large (75[1]); postparacrista reaching the lingual side of the mesostyle on upper molars $(53[1$ 
or 2]); postprotocrista absent on P4 (40[1]); paraconule absent on P3 (29[1]); diastema (d)p1p2 absent (87[0]); post-canine diastema absent (79[0]).

Node 3: [Hyracoidea + Proboscidea]. Two unambiguous synapomorphies supporting this clade are non-homoplastic: distocrista present at least on M1-M2 (45[1]) and talonid reduced on $\mathrm{p} 4(99[0])$. This node is relatively robust $(\mathrm{BI}=3)$.

Node 4: Proboscidea Illiger, 1811. This is the most robust node of the tree $(\mathrm{BI}=11)$. Seven out of eight unambiguous synapomorphies situated on that node are non-homoplastic:: preparacrista absent (49[1]) and mesostyle close to paracone and metacone (55[0]) on upper molars; paraconid absent or reduced on lower premolars (80[1]); cristid oblique slightly oblique with a mesial end reaching the labial half of trigonid (106[3]), premetacristid distinct (108[1]), and cristid oblique mesio-distally centered on lower molars (117[1]); labial hypoconulid on $\mathrm{m} 1-\mathrm{m} 2(127[1])$. The distal cingulum joins the hypocone via the distocrista $(46[0])$.

Node 5: [Embrithopoda + Phenacolophus fallax]. This node is highly robust $(\mathrm{BI}=5)$. Nine unambiguous synapomorphies (of which seven are non-homoplastic) supporting the close relationships of Phenacolophus fallax with embrithopods (node 5) are: large dental dimensions (consequently body size) (11[1]); preparacrista oriented rather transversally (51[0]), labio-lingually oriented postmetacrista (65[0]), absence of prehypocrista (69[0]) and metaloph formed by the alignment of hypocone, metaconule and metacone on upper molars (70[0]); lophids oblique compared with transversal axis on lower molars (114[0]); absence of hypoconulid on $\mathrm{m} 1-\mathrm{m} 2(126[1])$. Note that in the phylogenetic analyses of Gheerbrant et al. (2005) and Gheerbrant (2009), the hypoconulid is considered as present in embrithopods 
whereas it is considered as a strong cingulid on $\mathrm{m} 1$ and $\mathrm{m} 2$ instead in this analysis. The last two characters are: upper cheek tooth size increasing progressively from P2 towards M2, with M3 much larger on the dental series (72[1]); hypoconulid weak on m3 (128[1]).

Node 6: Embrithopoda Andrews, 1906. Three unambiguous synapomorphies support the monophyly of embrithopods (BI=3): upper molars hyper-dilambdodont (59[2]) and hypsodont (73[1]); lingual migration of the postparacrista, paracone and metacone on upper molars (53[3]). This character is non-applicable in A. zitteli (postparacrista absent) and not scored in Crivadiatherium (upper teeth unknown).

Node 7: Arsinoitheriidae Andrews, 1904. This node is the weakest node of the consensus tree $(\mathrm{BI}=1)$. Only two unambiguous synapomorphies (one of which is homoplastic) are supporting the family Arsinoitheriidae as a clade: labial cingulum absent on upper molars (47[1]); distal zygomatic process reaching the level of the distal loph of M3 (2[0 or 1]). This character is ordered and its ancestral state is 2 .

Node 8: Arsinoitheriinae Andrews, 1904. All four synapomorphies which characterise Arsinoitheriinae are non-homoplastic, hence, this node appears relatively robust $(\mathrm{BI}=3)$ : distal cingulum absent on upper molars (44[1]); trigonid and talonid having the same height on p2 and p3 (83[1]) as well as on lower molars (116[1]); mesial cingulid absent on lower molars $(102[1])$.

Node 9: Palaeoamasiinae Sen \& Heintz, 1979. This node is one of the less supported of the consensus tree $(\mathrm{BI}=2)$. Three unambiguous synapomorphies support Palaeoamasiinae, including two non-homoplastic characters: mesial end of the cristid oblique reaching the 
lingual middle of trigonid and elongated towards the apex of the metaconid on lower molars (106[0]); cristid oblique high and reaching the occlusal surface of the talonid (115[0]); threerooted P2 (20[1]).

\section{Phylogenetic position of Namatherium}

Nodes of the strict consensus tree are more or less well supported as regards BI (Fig. 5). In particular, the node 7 [Arsinoitheriinae, Palaeoamasiinae] is the weakest $(\mathrm{BI}=1)$ in bearing only two synapomorphies of which one is homoplastic (labial cingulum absent on upper molars; distal zygomatic process at the distal loph level of $\mathrm{M} 3[\mathrm{CI}=0.66 ; \mathrm{RI}=0.66])$. This node merits a further explanation since it excludes Namatherium from either Arsinoitheriinae (Arabian-African) or Palaeoamasiinae (Eurasian).

In order to estimate the potential affinity of Namatherium within those clades, two alternative topologies are forced via the tool 'Searching under Topological Constraints' in PAUP 3.1.1. Results are strongly significant, as the Arabian-African clade [Namatherium, Arsinoitherium] is then supported by three unambiguous synapomorphies (e.g. absence of postprotocrista on P3, absence of postmetacrista on upper molars, mesial and lingual cingula discontinuous on M3; Fig. 7A, branch $\mathrm{x}$ ) with a length of 244 steps. This is definitely more parsimonious compared to the topology where the clade [Namatherium, Palaeoamasiinae] is supported by 14 ambiguous synapomorphies, in a longer tree with 247 steps (Fig. 7B, node y). Noteworthy is the fact that only one additional step in the strict consensus tree $(\mathrm{L}=243+1)$ generates a trifurcation (as mentioned above).

The problematic position of Namatherium and unresolved relationships within Palaeoamasiinae arise probably from the sparse material directly comparable among embrithopods, which affects also the number of potential unambiguous synapomorphies (Table 5). For instance, Arsinoitherium zitteli and Palaeoamasia kansui are known by 
complete dental remains contrary to Namatherium and Hypsamasia, known only by upper teeth and to Crivadiatherium, known only by lower teeth.

\section{Contribution of the new material of Palaeoamasia kansui}

In order to control the possible relation between new specimens, abundance of comparable material and resolution of topologies, we tested four different scenarii (Fig. 8) and we obtained a posteriori (1) a topology where new specimens of $P$. kansui are removed (P2-P3 and mandible; Fig. 8A), (2) a topology excluding Hypsamasia (known by four damaged upper teeth; Fig. 8B), (3) a topology hypothesising a priori that Palaeamasia and Hypsamasia were synonyms (Fig. 8C) and (4) another hypothesis considering the two species of Crivadiatherium as a single terminal (Fig. 8D).

The results seem to be convincing since (i) the embrithopods and the clade Palaeoamasiinae are clearly supported through new material of P. kansui (Fig. 8A); (ii) the exclusion of Hypsamasia seni allows for a better phylogenetic resolution (resulting tree: 234 steps; Fig. 8B) and (iii) that resolution still increases when the hypodigms of both Crivadiatherium are amalgamated (232 steps; Fig. 8C). Note that whether Hypsamasia is excluded or combined with Palaeoamasia, the monophyly of Palaeoamasiinae and Crivadiatherium is retained. On the other hand, (iv) the topology of the general strict consensus tree (Fig. 5) is not affected when two species of Crivadiatherium are regarded as one (shorter tree: 236 steps instead of 243; Fig. 8D).

In any scenario, the node 7 of the general strict consensus tree (which excludes Namatherium from Palaeoamasiinae and Arsinoitheriinae, in the family Arsinoitheriidae) is as weak as in the main analysis $(\mathrm{BI}=1$; Fig. 5).

Overall, our phylogenetic results support the monophyly of Embrithopoda with one family, Arsinoitheriidae and two subfamilies, Palaeoamasiinae and Arsinoitheriinae (contra Kaya 
1995; Maas et al. 1998; Sanders et al. 2014) by excluding Namatherium from the family, which may change with a wider taxonomic sample and/or new findings of early embrithopods.

\section{Phylogenetic position of embrithopods within Paenungulata}

The phylogenetic position of embrithopods within Paenungulata and their possible affinities with Afrotheria are controlled with the inclusion of three genera, Palaeoamasia, Namatherium and Crivadiatherium, in the data matrix from Tabuce et al. (2007) wherein embrithopods were represented only by Arsinoitherium and appeared at the base of Paenungulata (Fig. 9A). The original matrix underwent some modifications concerning dental characters, with the decomposition of some multistate characters into binary characters and a few character state changes. By following the same protocols as in Tabuce et al. (2007: strict consensus and successive weighting), we obtained distinct topologies (Fig. 9B).

As to results, embrithopods are monophyletic and they are located at the base of ungulates and clearly separate from Phenacolophus and from Protosiren (Fig. 9B). While the branches $\mathrm{x}, \mathrm{y}$ and $\mathrm{z}$ of ungulates are supported by postcranial characters, the branch ' $\mathrm{t}$ ' is eventually supported only by molar features (Fig. 9B). Thus, it is clear that postcranial characters (unscored for embrithopods except Arsinoitherium) appear to be crucial for the resolution of interordinal phylogenetic relationships and that the systematic position of Phenacolophus is subjected to change depending either on the taxonomic sample or the phylogenetic characters scored. Also, Palaeoamasia is here sister taxon to other embrithopods contrary to the topology as illustrated in Figure 5.

\section{PALAEOBIOGEOGRAPHICAL IMPLICATIONS}


The previous strict consensus tree (Fig. 9B) makes possible to assume dispersal events within Ungulata between Eurasia and Africa (Fig. 10). According to the available taxonomic sample, there would be at least three dispersal events from Eurasia towards Africa (Macroscelidea; Hyracoidea + Tethytheria; Embrithopoda) and one reversal event with Anthracobune (Fig. $10 \mathrm{~A})$.

Detailed analysis of three equally parsimonious trees concerning embrithopods (Fig. 10B) point to three dispersal hypotheses, such as (1) one event from Eurasia to Africa at the base of the clade [Arsinoitherium, Namatherium], (2) two events, with the first one from Eurasia to Africa for the clade which excludes Palaeoamasia and a second one from Africa to Eurasia for Crivadiatherium, (3) two independent dispersal events from Eurasia to Africa for Namatherium and Arsinoitherium.

The most parsimonious topology is one with a single dispersal event (Fig. 10B: $\mathrm{x}$ ). This analysis would confirm the Eurasian origin of embrithopods, as proposed formerly by Radulesco et al. (1976), McKenna \& Manning (1977), Sen \& Heintz (1979), and Radulesco $\&$ Sudre (1985). Following a more general context, such as palaeogeography, eustatic curves, fossil record and phylogeny, dispersal events took place either in Thanetian times or before the Ypresian-Lutetian transition (Fig. 11). According to Gheerbrant \& Rage (2006), two faunal exchange events probably occurred during the Thanetian interval (Fig. 11A). There is a huge gap in the Arabian-African fossil record, between the latest Paleocene and the Lutetian. Future prospects must focus on this time interval in order to shed light on dispersal events of embrithopods. On the other hand, the recent recognition of Palaeoamasia around the EoceneOligocene transition in Turkey (Sanders et al. 2014) illustrates the existence of another ghost lineage encompassing the middle-late Eocene interval (Fig. 11) and would further point to a morphological stasis within Palaeoamasia, at least for the available characters. We do agree with Sen (2013) that some possible sweepstake passage of embrithopods existed during the 
Palaeogene interval, most probably during the late Paleocene which perhaps allowed Eurasian embrithopods to disperse to Arabia-Africa.

\section{CONCLUSION}

New material of Palaeoamasia kansui from the type locality Eski-Çeltek (Amasya, Turkey) enhances our cranial-dental knowledge concerning Eurasian embrithopods. A phylogenetic analysis at the species-level demonstrates the monophyly of Embrithopoda. Namatherium blackcrowense Pickford et al. 2008, from the middle Eocene of Namibia, is the first offshoot within Embrithopoda. It is sister group to the monophyletic family Arsinoitheriidae, divided in two subfamilies. Arsinoitheriinae comprise other Arabian-African embrithopods (Arsinoitherium zitteli, A. giganteum) and Palaeoamasiinae include all Eurasian embrithopods (Palaeoamasia, Hypsamasia, Crivadiatherium). The position of Namatherium outside Arsinoitheriinae/Arsinoitheriidae is weakly supported. Phylogenetic relationships within Palaeoamasiinae are not totally resolved either. Palaeoamasia remains from Boyabat (Sanders et al. 2014) are here conservatively assigned to P. kansui. This new evidence is an encouraging hint to prospect further in mid-Palaeogene deposits of Turkey and Balkans, in order to clarify the phylogenetic affinities of Eurasian embrithopods.

Acknowledgements. The authors owe many thanks to Philippe Loubry (MNHN, Paris) for photographs of the material, Rodolphe Tabuce for his critical publication supplies and his own data matrix, Maëva Orliac for her guidance on cladistic softwares and her encouragements, Monique Vianey-Liaud and Laurent Marivaux for their advices, Christine Bibal and MaryAlice Garcia for their kindness (ISEM, Montpellier). 


\section{REFERENCES}

AL-SAYIGH, A.R., NASIR, S., SCHULP, A.S. and STEVENS, N.J. 2008. The first described Arsinoitherium from the upper Eocene Aydim Formation of Oman: Biogeographic implications. Palaeoworld, 17, 41-46.

ANDREWS, C.W. 1904. Note on the Barypoda, a new Order of Ungulate Mammals. Geological Magazine Decade V, 1, 481-482.

— 1906. A Descriptive Catalogue of the Tertiary Vertebrata of the Fayûm, Egypt, Based on the Collection of the Egyptian Government in the Geological Museum, Cairo, and on the Collection of the British Museum (Natural History). Bulletin of the British Museum (Natural History), London, 324 p.

ANTOINE, P.-O. 2002. Phylogénie et évolution des Elasmotheriina (Mammalia, Rhinocerotidae). Mémoires du Muséum national d'Histoire naturelle, Paris, 188, 1-359.

ARCHIBALD, J.D., 2003. Timing and biogeography of the Eutherian radiation: fossils and molecules compared. Molecular Phylogenetics and Evolution, 28, 350-359.

BARRIER, E. and VRIELYNCK, B. 2008. Palaeotectonic maps of the Middle East. Tectonosedimentary-palinspastic maps from late Norian to Pliocene. CGMW/CCGM, Paris (14 maps).

BENOIT, J., MERIGEAUD, S. and TABUCE, R. 2013. Homoplasy in the ear region of Tethytheria and the systematic position of Embrithopoda (Mammalia, Afrotheria). Geobios, 46, 357-370.

— CROCHET, J. Y., MAHBOUBI, M., JAEGER, J. J., BENSALAH, M., ADACI, M. and TABUCE, R. 2015. New material of Seggeurius amourensis (Paenungulata, Hyracoidea), including a partial skull with intact basicranium. Journal of Vertebrate Paleontology, 36:1, e1034358. DOI: 10.1080/02724634.2015.1034358 
BOSCHETTO, H.B., BROWN, F.H. and MCDOUGALL, I. 1992. Stratigraphy of the Lothidok Range, northern Kenya, and K/Ar ages of its Miocene primates. Journal of Human Evolution, 22, 47-71.

BOWN, T. M. and KIHM, A. J. 1981. Xenicohippus, an unusual new hyracotheriine (Mammalia, Perissodactyla) from lower Eocene rocks of Wyoming, Colorado and New Mexico. Journal of Paleontology, 55, 257-270.

BREMER, K. 1994. Branch support and tree stability. Cladistics, 10, 295-304.

CLEMENTZ, M.T., HOLROYD, P.A. and KOCH, P.L. 2008. Identifying aquatic habits of herbivorous mammals through stable isotope analysis. Palaios, 23, 574-585.

COPE, E. D. 1880. The bad lands of the Wing River and their fauna. The American Naturalist 14(10), 745-748.

COOPER, L. N., SEIFFERT, E. R., CLEMENTZ, M., MADAR, S. I., BAJPAI, S., HUSSAIN, S. T. and THEWISSEN, J. G. 2014. Anthracobunids from the middle Eocene of India and Pakistan are stem perissodactyls. PLoS ONE, 9(10), e109232.

COURT, N. 1992b. A unique form of dental bilophodonty and a functional interpretation of peculiarities in the masticatory system of Arsinoitherium (Mammalia, Embrithopoda). Historical Biology, 6, 91-111.

— 1992c. The skull of Arsinoitherium (Mammalia, Embrithopoda) and the higher order interrelationships of ungulates. Palaeovertebrata, 22, 1-43.

— 1993. Morphology and functional anatomy of the postcranial skeleton in Arsinoitherium (Mammalia, Embrithopoda): Palaeontographica. Abteilung A, Palä̈zoologie-stratigraphie, 226, $125-169$.

— and MAHBOUBI, M. 1993. Reassessment of lower Eocene Seggeurius amourensis: aspect of primitive dental morphology in the mammalian order Hyracoidea. Journal of Paleontology, 67, 889-893. 
DAMUTH, J. and JANIS, C.M. 2011. On the relationship between hypsodonty and feeding ecology in ungulate mammals, and its utility in palaeoecology. Biological Reviews, 86, 733758.

DELMER, C. 2005. Les premières phases de différenciation des Proboscidiens (Tethytheria, Mammalia): le rôle du Barytherium grave de Lybie. Thèse de Doctorat, MNHN, 443 p. (unpublished).

FROEHLICH, D.W. 2002. Quo vadis Eohippus? The systematics and taxonomy of the early Eocene equids (Perissodactyla). Zoological Journal of the Linnean Society, 134, 141-256.

GHEERBRANT, E. 2009. Paleocene emergence of elephant relatives and the rapid radiation of African ungulates. Proceedings of the National Academy of Sciences, 106, 10717-10721. — and RAGE, J.C. 2006. Paleobiogeography of Africa: how distinct from Gondwana and Laurasia? Palaeogeography, Palaeoclimatology, Palaeoecology, 241, 224-246.

— and TASSY, P. 2009. L'origine et l'évolution des elephants. Comptes Rendus Palevol, 8, 281-294.

— SUDRE, J. and CAPPETTA, H. 1996. A Palaeocene proboscidean from Morocco. Nature, 383, 68-70.

— DOMMING, D.P. and TASSY, P. 2005b. Paenungulata (Sirenia, Proboscidea, Hyracoidea, and relatives). 84-105. In Rose, K. D. and Archibald, J. D. (eds). Placental mammals: origins and relationships of the major clades. Johns Hopkins University Press, Baltimore.

— SUDRE, J., CAPPETTA, H. and BIGNOT, G. 1998. Phosphatherium escuilliei du Thanétien du Bassin des Ouled Abdoun (Maroc), plus ancien proboscidien (Mammalia) d'Afrique. Geobios, 31(2), 247-269. 
— AMAGHZAZ, M., BOUYA, B., GOUSSARD, F. and LETENNEUR, C. 2014. Ocepeia (Middle Paleocene of Morocco): The oldest skull of an afrotherian mammal. PloS One, 9(2), e89739. doi: 10.1371/journal.pone.0089739

— SUDRE, J., CAPPETTA, H., IAROCHÈNE, M., AMAGHZAZ, M. and BOUYA, B. 2002. A new large mammal from the Ypresian of Morocco: evidence of surprising diversity of early proboscideans. Acta Palaeontologica Polonica, 47, 493-506.

— SUDRE, J., TASSY, P., AMAGHZAZ, M., BOUYA, B. and IAROCHÈNE, M. 2005a. Nouvelles données sur Phosphatherium escuilliei (Mammalia, Proboscidea) de l'Eocène inférieur du Maroc, apports à la phylogénie des Proboscidea et des ongulés lophodontes. Geodiversitas, 27, 239-333.

GINGERICH, P.D. 1991. Systematics and evolution of Early Eocene Perissodactyla (Mammalia) in the Clarks Fork Basin, Wyoming. Contributions from the Museum of Paleontology, University of Michigan, 28(8), 181-213.

GÜL, A. 2003. Orhaniye-Güvenç civarindaki (Ankara KB'si) karasal Paleojen birimlerinin stratigrafisi ve sedimantolojisi. Ankara Üniversitesi, Fen Bilimleri Enstitüsü, Yüksek Lisans Tezi (unpublished).

HUTCHINSON, J.R., DELMER, C., MILLER, C. E., HILDEBRANDT, T., PITSILLIDES, A. A. and BOYDE, A. 2011. From flat foot to fat foot: Structure, ontogeny, function, and evolution of elephant "sixth toes". Science, 334, 1699-1703.

KAPPELMAN, J., MAAS, M., SEN, S., ALPAGUT, B., FORTELIUS, M. and LUNKKA, J.P. 1996. A new early Tertiary mammalian fauna from Turkey and its paleobiogeographic significance. Journal of Vertebrate Paleontology, 16, 592-595.

— RASMUSSEN, D. T., SANDERS, W. J., FESEHA, M., BOWN, T., COPELAND, P., CRABAUGH, J., FLEAGLE, J., GLANTZ, M., GORDON, A., JACOBS, B., MAGA, M., MULDOON, K., PAN, A., PYNE, L., RICHMOND, B., RYAN, T., SEIFFERT, E., SEN, S., 
TODD, L., WIEMANN, M. C. and WINKLER. A. 2003. Oligocene mammals from Ethiopia and faunal exchange between Afro-Arabia and Eurasia. Nature, 426, 549-552.

KAYA, T. 1995. Palaeoamasia kansui (Mammalia) in the Eocene of Bultu-Zile (TokatNortheastern Turkey) and systematic revision of Palaeoamasia. Turkish Journal of Earth Sciences, 4, 105-111.

KAZANCI, N. and GÖKTEN, E. 1986. Sedimentary characteristics of terrestrial Paleocene deposits in northern Ankara Region, Turkey. Communications de la Faculté des Sciences, Université d'Ankara, C4, 153-163.

KITTS, D. B. 1956. American Hyracotherium (Perissodactyla, Equidae). American Museum of Natural History Bulletin, 110, 1-60.

KOÇ, C. and TÜRKMEN, I. 2002. Sedimentological characteristics of coal-bearing Eocene sediments in the north of Suluova (Amasya) (Turkish, English abstract). Bulletin for Earth Sciences, Hacettepe University, 26, 101-117.

MAAS, M. C., THEWISSEN, J. G. M. and KAPPELMAN, J. 1998. Hypsamasia seni (Mammalia, Embrithopoda) and other mammals from the Eocene Kartal Formation of Turkey. Bulletin of Carnegie Museum of Natural History, 34, 286-297.

— THEWISSEN, J. G. M., SEN, S., KAZANCI, N. and KAPPELMAN, J. 2001. Enigmatic new ungulates from the early Middle Eocene of Central Anatolia, Turkey. Journal of Vertebrate Paleontology, 21, 578-590.

MAO, F. Y., WANG, Y. Q., LI, Q. and JIN, X. 2015. New records of archaic ungulates from the Lower Eocene of Sanshui Basin, Guangdong, China. Historical Biology, 1-16.

MATTHEW, W. D. and GRANGER, W. 1925. Fauna and correlation of the Gashato Formation of Mongolia. American Museum Novitates, 189, 1-12. 
MCKENNA, M.C. 1975. Toward a phylogenetic classification of the Mammalia. 21-46. In Luckett, W. P. and Szalay, F. S. (eds). Phylogeny of the Primates: A Multidisciplinary Approach. Plenum Press New York.

— and BELL, S. K. 1997. Classification of Mammals above the Species Level. Columbia University Press, New York, ix +631 p.

- and MANNING, E. 1977. Affinities and palaeobiogeographic significance of the Mongolian Paleogene genus Phenacolophus. Geobios. Mémoire special, 1, 61-85.

— CHOW, M., TING, S. and LUO, Z. 1989. Radinskya yupingae, a perissodactyl-like mammal from the late Paleocene of China. 24-36. In Prothero, D. R. and Schoch, R. M. (eds). The Evolution of Perissodactyls. Oxford University Press.

MEREDITH, R. W., JANECKA, J. E., GATESY, J., RYDER, O. A., FISHER, C. A., TEELING, E. C., GOODBLA, A., EIZIRIK, E., SIMÃO, T. L. L., STADLER, T., RABOSKY, D. L., HONEYCUTT, R. L., FLYNN, J. J., INGRAM, C. M., STEINER, C., WILLIAMS, T. L., ROBINSON, T. J., BURK-HERRICK, A., WESTERMAN, M., AYOUB, N. A., SPRINGER, M. S., WILLIAM J. and MURPHY, W. J. 2011. Impacts of the Cretaceous terrestrial revolution and $\mathrm{K} / \mathrm{Pg}$ extinction on mammal diversification. Science, 334, 521-524.

MÉTAIS, G., GHEERBRANT, E. and SEN, S. 2012. Re-interpretation of the genus Parabunodon (Ypresian, Turkey): Implications for the evolution and distribution of pleuraspidotheriid mammals. Palaeobiodiversity and Palaeoenvironments, 92, 477- 486. MOUSTAPHA, W. 1955. An interpretation of Arsinoitherium. Bulletin de l'Institut d'Egypte, 36, 111-118.

NIXON, K.C. 1999.Winclada Version 1.00.08. Software published by the author, Ithaca, N.Y. NOVACEK, M. J. 1986. The skull of leptictid insectivorans and the higher-level classification of eutherian mammals. Bulletin of the American Museum of Natural History, 183, 1-111. 
— and WYSS, A. R. 1986. Higher-level relationships of the recent eutherian orders: morphological evidence Cladistics, 2(4), 257-287.

ORLIAC, M. J., ANTOINE, P-O. and DUCROCQ, S. 2010. Phylogenetic relationships of the Suidae (Mammalia, Cetartiodactyla): new insights on the relationships within Suoidea. Zoologica Scripta, 39(4), 315-330.

OZANSOY, F. 1966. Türkiye Senozoik çaglarinda fosil insan formu problemi ve biostratigrafik dayanaklari. Ankara University D.T.C.F. Yayinlari, 172, 1-104.

_ 1969. Yeni bir Palaeoamasia kansui, Boyabat (Sinop) Eosen fosil memeli biozonu ve paleontolojik belgeleri. Türk Tarih Kurumu Belleten, Ankara, 33, 581-585.

PAGE, R. D. M. 2001. NDE: NEXUS Data Editor for Windows. Glasgow.

PICKFORD, M. 1986. Première découverte d'une faune mammalienne terrestre paléogène d'Afrique sub-saharienne. Comptes Rendus de l'Académie des Sciences, Paris. Sér. II 302, $1205-1210$.

— SENUT, B., MORALES, J., MEIN, P. and SANCHEZ, I. 2008. Mammalia from the Lutetian of Namibia. Geological Survey of Namibia Memoir, 20, 465-514.

RADULESCO, C. and SAMSON, P. 1987. Eocene mammals from Romania with a review of Embrithopods. The Eocene from the Transylvanian Basin, Cluj-Napoca, 135-142.

— and SUDRE, J. 1985. Crivadiatherium iliescu n. sp., nouvel embrithopode (Mammalia) dans le Paléogène ancien de la Dépression de Hateg (Roumanie). Palaeovertebrata, 15, $139-157$.

— ILIESCO, G. and ILIESCO, M. 1976. Un Embrithopode nouveau (Mammalia) dans le Paléogène de la Dépression de Hateg (Roumanie) et la géologie de la région. Neues Jahrbuch für Geologie und Paläontologie, 11, 690-698. 
RASMUSSEN, D. T., TSHAKREEN, S. O., ABUGARES, M. M. and SMITH, J. B. 2008. Return to Dor al-Talha. In Elwyn Simons: A Search for Origins. Springer New York, 181196.

— and GUTIÉRREZ, M. 2010. Hyracoidea. 123-145. In Werdelin, L.and Sanders, W. J. (eds). Cenozoic Mammals of Africa. University of California Press, Berkeley.

ROSE, K. D., HOLBROOK, L. T., RANA, R. S., KUMAR, K., JONES, K. E., AHRENS, H. E., MISSIAEN, P., SAHNI, A. and SMITH, T. 2014. Early Eocene fossils suggest that the mammalian order Perissodactyla originated in India. Nature communications, 5, 5570. doi: $10.1038 /$ ncomms 6570

SANDERS, W. J., KAPPELMAN, J. and RASMUSSEN, D. T. 2004. New large-bodied mammals from the late Oligocene site of Chilga, Ethiopia. Acta Palaeontologica Polonica, 49, 365-392.

— RASMUSSEN, D. T. and KAPPELMAN, J. 2010. Embrithopoda. 603-657. In Werdelin, L.and Sanders, W. J. (eds). Cenozoic mammals of Africa. University of California Press, Berkeley.

— NEMEC, W., ALDINUCCI, M., JANBU, N. E. and GHINASSI, M. 2014. Latest evidence of Palaeoamasia (Mammalia, Embrithopoda) in Turkish Anatolia. Journal of Vertebrate Paleontology, 34(5), 1155-1164.

SEIFFERT, E. R. 2006. Revised age estimate for the later Paleogene mammal faunas of Egypt and Oman. Proceedings of the National Academy of Sciences, 103, 5000-5005.

_ 2007. A new estimate of afrotherian phylogeny based on simultaneous analysis of genomic, morphological, and fossil evidence. BMC Evolutionary Biology, 7, 224. doi:10.1186/1471-2148-7-224

SEN, S. and HEINTZ, E. 1979. Palaeoamasia kansui Ozansoy 1966, Embrithopode (Mammalia) de l'Eocène d'Anatolie. Annales de Paléontologie (Vertébrés), 65, 73-91. 
_ 2013. Dispersal of African mammals in Eurasia during the Cenozoic: ways and whys. Geobios, 46(1), 159-172.

SIMPSON, G. G. 1945. The principles of classification and a classification of mammals. Bulletin of the American Museum of Natural History, 85, 1-350.

SPRINGER, M. S., MEREDITH, R. W., JANECKA, J. E. and MURPHY, W. J. 2011. The historical biogeography of Mammalia. Philosophical Transactions of the Royal Society, B366, 2478-2502.

SWOFFORD, D. L. 1993. PAUP v. 3.1. User's Manual. Illinois Natural History Survey, Champaign, software.

TABUCE R., ASHER, R. and LEHMANN, T. 2008. Afrotherian mammals: a review of current data. Mammalia, 72, 2-14.

— MARIVAUX, L., ADACI, M., BENSALAH, M., HARTENBERGER, J-L., MAHBOUBI, M., MEBROUK, F., TAFFOREAU, F. and JAEGER, J-J. 2007. Data from: Early Tertiary mammals from North Africa reinforce the molecular Afrotheria clade. Proceedings of the Royal Society, B274, 1159-1166.

THENIUS, E. 1969. Stammesgeschichte der Säugetiere (einschliesslich der Hominiden). Handbuch der Zoologie, 8(47), 1-368.

THOMAS, H., ROGER, J., SEN, S., BOURDILLON-DE-GRISSAC, C. and ALSULAIMANI, Z. 1989. Découverte de Vertébrés fossiles dans l'Oligocène inférieur du Dhofar (Sultanat d'Oman). Geobios, 22, 101-120.

— ROGER, J., SEN, S., PICKFORD, M., GHEERBRANT, E., AL-SULAIMANI, Z. and AL-BUSAIDI, S. 1999. Oligocene and Miocene terrestrial vertebrates in the Southern Arabian Peninsula (Sultanate of Oman) and their geodynamic and palaeogeographic settings. 430-442. In Whybrow, P. J. and Hill, A. (eds). Fossil Vertebrates of Arabia. Yale University Press, New Haven. 
WIGHT, A. W. R. 1980. Paleogene vertebrate fauna and regressive sediments of Dur at Talhah, southern Sirt Basin, Libya. 309-325. In Salem, M. J. and Busrewil, M. T. (eds). The Geology of Libya, Academic Press, London.

ZALMOUT, I. S., SANDERS, W. J., MACLATCHY, L. M., GUNNELL, G. F., ALMUFARREH, Y. A., ALI, M. A., NASSER, A. H., AL-MASARI, A. M., AL-SOBHI, S. A., NADHRA, A. O., MATARI, A. H., WILSON, J. A. and GINGERICH, P. D. 2010. New Oligocene primate from Saudi Arabia and the divergence of apes and Old World monkeys. Nature, 466, 360-365. 


\section{Figure, table and appendix captions}

Fig. 1. Spatial and temporal distribution of embrithopods. Numbers follow the chronological order of localities (see also Table 1). Chronological distribution of localities (A) (modified after International Stratigraphic Chart, 2015/1); geographical distribution of studied specimens on a contemporary map (B); localities of Palaeoamasia and Hypsamasia on the contemporary map of Turkey (C). Localities are in the same colour as ones of the geological chart. Lowercase letters indicate different localities of Palaeoamasia kansui.

Fig. 2. Dental terminology used in this study. A-C, upper left teeth; D-E, lower left teeth. P2 (A); P4 (B); M2 (C); p2 (D); p4 (E); m3 (F). Terminology is combined after descriptions of McKenna \& Manning (1977), Sen \& Heintz (1979), Iliescu \& Sudre (1985), Court (1992b), Maas et al. (1998), Sanders et al. (2004) and Pickford et al. (2008).

Fig. 3. Holotype and new specimens of Palaeoamasia kansui Ozansoy, 1966 (from the late Paleocene - early Eocene of Eski-Çeltek, Amasya-Turkey). A-B, holotype, MNHN-EÇ-1, left mandible fragment with highly damaged trigonid of $\mathrm{m} 1, \mathrm{~m} 2$ and trigonid of $\mathrm{m} 3$. The relatively complete specimen is illustrated by Ozansoy (1966, fig. 3-4). C-D, ITU-EÇ-8, left P2-P3; E-F, ITU-EÇ-7, palate fragment with right P4-M2; G, MNHN-EÇ-6, isolated left M3; H-J, ITU-EÇ9, mandible fragment with left p2-m1; K-L, MNHN-EÇ-5, mandible fragment with right p4m1. Views are occlusal (A, C, E, G, H, K), labial (B, D, F, J, L), and lingual (I). Scale bar equals 2 cm. Photographs: Philippe Loubry (MNHN, Paris). 
Fig. 4. Size distribution of upper (A) and lower (B) premolars and molars of embrithopods by mean values in mm. Crivadiatherium, Hypsamasia, and new material of Palaeoamasia kansui are re-measured by authors. For other measurements see McKenna \& Manning (1977), Sen \& Heintz (1979), Kaya (1995), A. Gül, unpub. data (2003), Sanders et al. (2004, 2014), Pickford et al. (2008). Mean values are available in Appendix 3. Colours indicate tooth type, symbols distinguish taxa. Only comparable tooth types are included in this diagram (e.g. incisors of Crivadiatherium or p1 of $A$. giganteum are not included). M1-M3 of Ph. fallax is highly damaged and lacks the measurements. L, length; W, width.

Fig. 5. Strict consensus tree $(\mathrm{L}=243$ steps, $\mathrm{CI}=0.588$ and $\mathrm{RI}=0.587)$ of ten shortest trees ( $\mathrm{L}=237$ steps, $\mathrm{CI}=0.603, \mathrm{RI}=0.612$ ) obtained with PAUP 3.1 .1 based on 130 cranial and dental characters (character list and data matrix supplied in Appendices 1-2). Number of synapomorphies of each node is mentioned in italics, Bremer Indices in bold; node numbers in circle.

Fig. 6. Detail of the most parsimonious trees concerning Palaeoamasiinae ( $L=237$ steps, $\mathrm{CI}=0.603, \mathrm{RI}=0.612$ ). Five alternative topologies of Eurasian embrithopods acquired by PAUP 3.1.1. The letters in lowercase indicate nodes. Note that nodes $\mathrm{x}$ and $\mathrm{w}$ reappear in different trees.

Fig. 7. Comparison of alternative topologies implying Namatherium. (A) Strict consensus $(\mathrm{L}=244, \mathrm{CI}=0.586, \mathrm{RI}=0.583)$ of ten equally parsimonious trees with the node $\mathrm{x}$ (Namatherium + Arsinoitherium) . (B) Strict consensus ( $\mathrm{L}=247, \mathrm{CI}=0.579, \mathrm{RI}=0.570)$ of ten equally parsimonious trees with the node y (Namatherium+Palaeoamasiinae). L, branch length; $x$, three unambiguous synapomorphies; $y$, fourteen ambiguous synapomorphies. 
Fig. 8. Strict consensus tree topologies obtained by following different scenarii. Topology acquired $(\mathrm{L}=243, \mathrm{CI}=0.588, \mathrm{RI}=0.567)$ with exclusion of new specimens of Palaeoamasia kansui (A); topology acquired ( $\mathrm{L}=234, \mathrm{CI}=0.611, \mathrm{RI}=0.596)$ with exclusion of Hypsamasia seni (B); topology acquired ( $\mathrm{L}=232, \mathrm{CI}=0.612, \mathrm{RI}=0.598)$ under hypothesis of PalaeoamasiaHypsamasia synonymy $(\mathrm{C})$; topology acquired $(\mathrm{L}=236, \mathrm{CI}=0.602, \mathrm{RI}=0.593)$ where Crivadiatherium is terminal taxon (D). Numbers correspond to Bremer indices.

Fig. 9. Comparison of strict consensus trees established after successive weighting process following the data matrix of Tabuce et al. (2007). Topology published in Tabuce et al. (2007) (A; $\mathrm{L}=49166, \mathrm{CI}=0.43, \mathrm{RI}=0.67$ ). Topology obtained with the same protocol after including other embrithopods such as Namatherium, Crivadiatherium and Palaeoamasia (B; L=47841, $\mathrm{CI}=0.44, \mathrm{RI}=0.66$ ). Lowercase letters indicate characters supporting the concerned node: two unambiguous postcranial characters $(\mathrm{x})$; three unambiguous postcranial characters $(\mathrm{y})$; two unambiguous postcranial characters $(\mathrm{z})$ and one unambiguous dental character $(\mathrm{t})$ (Tabuce et al. 2007).

Fig. 10. Dispersal event hypothesis of Ungulata between Eurasia and Arabian-African continent. Topology displaying four dispersal events within Ungulata (modified after Tabuce et al. 2007) (A); Alternative topology concerning embrithopods illustrates three different dispersal events hypotheses (B). Green lines, Eurasian origin taxa; orange lines, ArabianAfrican origin taxa; grey lines, marine taxa; arrows, direction of migration. Lower case letters indicate different topologies with one (x, parsimonious) or two dispersal events (y and y'). 
Fig. 11. Stratigraphical and palaeogeographical distribution of embrithopods in a phylogenetic framework (A). Distribution and hypothetical dispersal events for embrithopods (B). Colour codes on the map equal those of the phylogenetic tree in A. Palaeogeographical map at Ypresian times is modified after Barrier \& Vrielynck (2008) and Sen (2013). Geological time scale is modified after International Stratigraphic Chart (2015/1). Eustatic curve is modified after Gheerbrant \& Rage (2006). Arrows display possible faunal exchange events between Eurasia and Afro-Arabia.

Table 1. List of embrithopods (and Phenacolophus fallax) in stratigraphical order with corresponding localities, time interval, authors and locality numbers given in Figure 1.

Table 2. Interordinal classification of Embrithopoda (parenthetical mode) according to previous authors. Underlined taxon names followed by a colon are for higher-taxa.

Table 3. Dental measurements (in mm) of new material of Palaeoamasia kansui, and casts of Hypsamasia seni, Crivadiatherium mackennai and C. iliescui specimens.

Table 4. List of unambiguous apomorphies on nodes of the strict consensus tree. Unambiguous and non-homoplastic characters are in bold, unambiguous autapomorphies of which corresponding state is not homoplastic are in italics and unambiguous and weakly homoplastic characters $(0.75 \leq \mathrm{RI}<1)$ are underlined. Homoplastic characters $(\mathrm{RI}<0.75)$ lack any annotations. Each character state is mentioned in brackets. Ambiguous characters are excluded from that list. Complete distribution of characters is in Appendix 4. 
1

2

3

4

5

6

7

8

9

10

11

12

13

14

15

16

17

18

19

20

21

22

23

24

25

26

27

28

29

30

31

32

33

34

35

36

37

38

39

40

41

42

43

44

45

46

47

48

49

50

51

52

53

54

55

56

57

58

59

60

Table 5. Number of characters scored for Arsinoitherium, Palaeoamasia, Namatherium, Crivadiatherium and Hypsamasia species depending on available specimens. 
Fig. 1. Spatial and temporal distribution of embrithopods. Numbers follow the chronological order of localities (see also Table 1). Chronological distribution of localities (A) (modified after International Stratigraphic Chart, 2015/1); geographical distribution of studied specimens on a contemporary map (B); localities of Palaeoamasia and Hypsamasia on the contemporary map of Turkey (C). Localities are in the same colour as ones of the geological chart. Lowercase letters indicate different localities of Palaeoamasia kansui. 
1

2

3

4

5

8

9

10

11

12

13

14

15

16

17

18

19

20

21

22

23

24

25

26

27

28

29

30

31

32

33

34

35

36

37

38

39

40

41

42

43

44

45

46

47

48

49

50

51

52

53

54

55

56

57

58

59

60
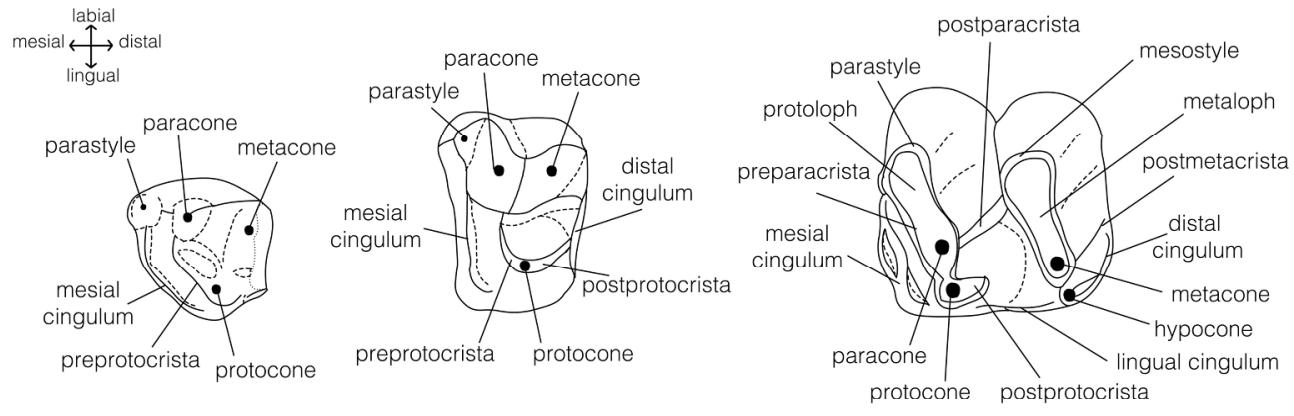

A

B

C

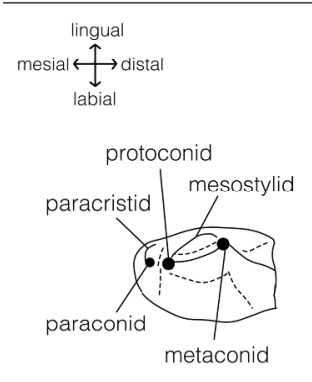

D

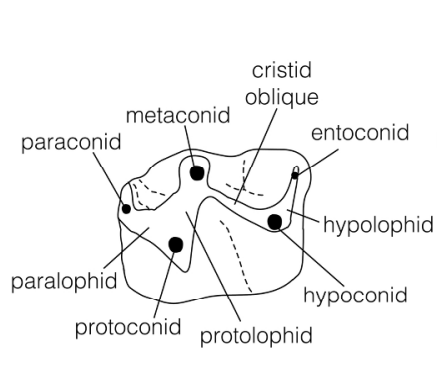

E

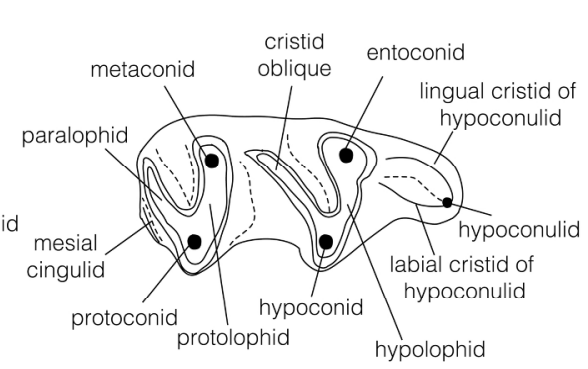

F

Fig. 2. Dental terminology used in this study. A-C, upper left teeth; D-E, lower left teeth. P2 (A); P4 (B); M2 (C); p2 (D); p4 (E); m3 (F). Terminology is combined after descriptions of McKenna \& Manning (1977), Sen \& Heintz (1979), Iliescu \& Sudre (1985), Court (1992b), Maas et al. (1998), Sanders et al. (2004) and Pickford et al. (2008). $111 \times 79 \mathrm{~mm}(600 \times 600 \mathrm{DPI})$ 

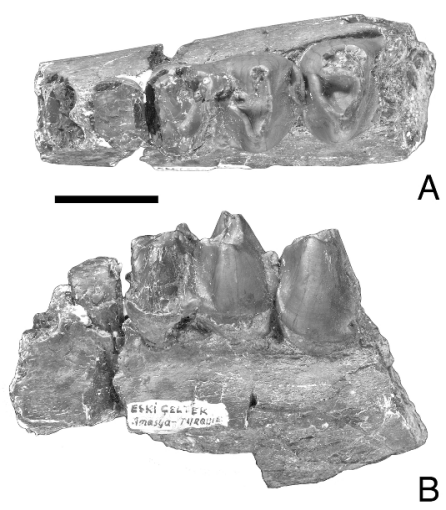

A

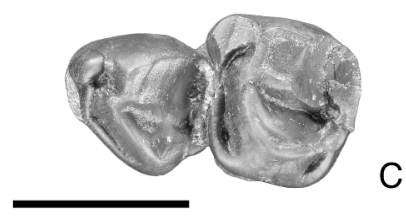

B
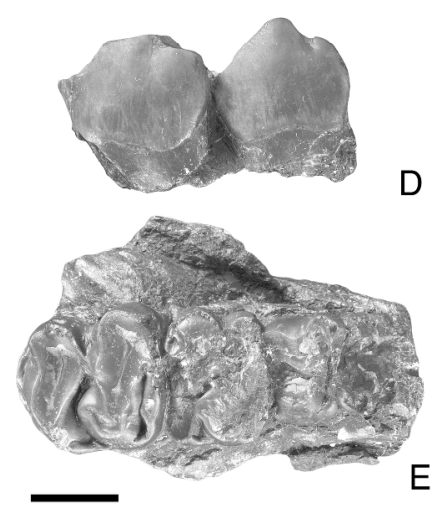

E

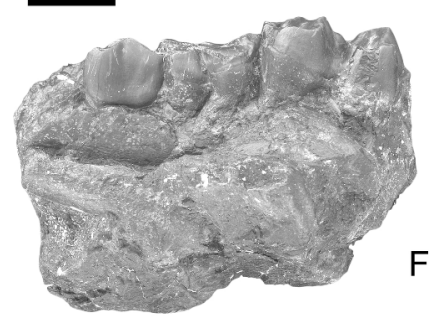

F

Fig. 3. Holotype and new specimens of Palaeoamasia kansui Ozansoy, 1966 (from the late Paleocene - early Eocene of Eski-Çeltek, Amasya-Turkey). A-B, holotype, MNHN-EÇ-1, left mandible fragment with highly damaged trigonid of $\mathrm{m} 1, \mathrm{~m} 2$ and trigonid of $\mathrm{m} 3$. The relatively complete specimen is illustrated by Ozansoy (1966, fig. 3-4). C-D, ITU-EÇ-8, left P2-P3; E-F, ITU-EC-7, palate fragment with right P4-M2; G, MNHNEÇ-6, isolated left M3; H-J, ITU-EÇ-9, mandible fragment with left p2-m1; K-L, MNHN-EC -5, mandible fragment with right $\mathrm{p} 4-\mathrm{m} 1$. Views are occlusal $(A, C, E, G, H, K)$, labial (B, D, F, J, L), and lingual (I). Scale bar equals $2 \mathrm{~cm}$. Photographs: Philippe Loubry (MNHN, Paris). $225 \times 307 \mathrm{~mm}(300 \times 300 \mathrm{DPI})$ 

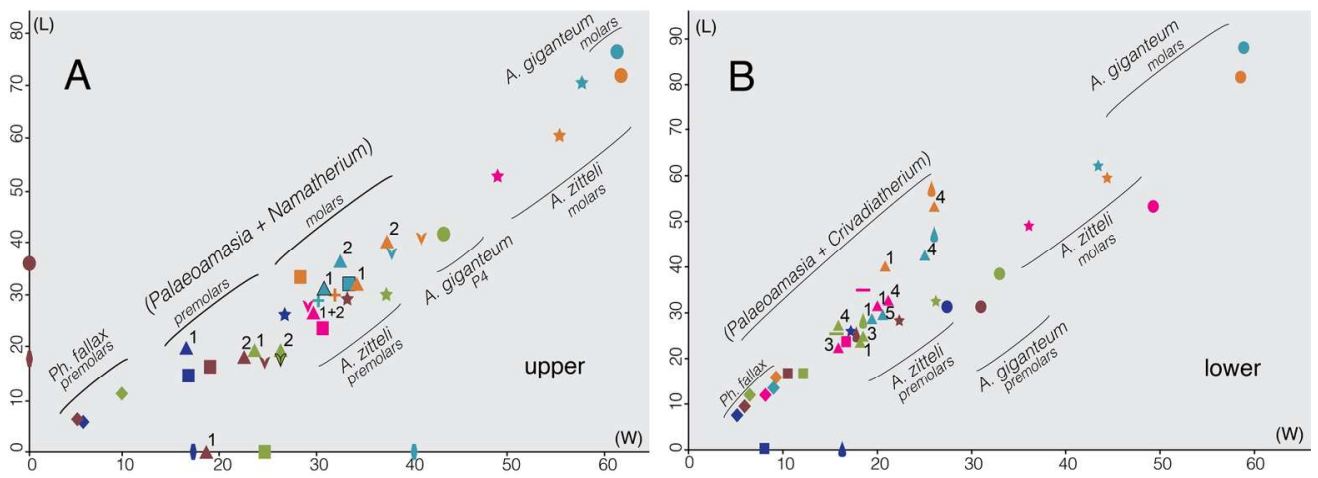

\begin{tabular}{|c|c|c|c|c|c|}
\hline $\mathrm{P} 2 / \mathrm{p} 2$ & $\mathrm{M} 1 / \mathrm{m} 1$ & $\diamond P h$. fallax & $\triangle P$. kansui & O Hypsamasia & $\vee$ Namatherium \\
\hline P3/p3 & $\mathrm{M} 2 / \mathrm{m} 2$ & $\square \underset{\text { (present study) }}{P . k a n s u i}$ & $\begin{array}{l}\text { (1) Eski-Celtek, (2) Orhaniye } \\
\text { (3) Boyabat, (4) Cicędağ }\end{array}$ & 口 C. mackennai & is a zitteli \\
\hline $\mathrm{P} 4 / \mathrm{p} 4$ & $\mathrm{M} 3 / \mathrm{m} 3$ & + BOY-2 & $\begin{array}{l}\text { (5) Bultu-Zile } \\
\text { (N) }\end{array}$ & $\Delta$ c. iliescui & A. giganteum \\
\hline
\end{tabular}

Fig. 4. Size distribution of upper (A) and lower (B) premolars and molars of embrithopods by mean values in $\mathrm{mm}$. Crivadiatherium, Hypsamasia, and new material of Palaeoamasia kansui are re-measured by authors. For other measurements see McKenna \& Manning (1977), Sen \& Heintz (1979), Kaya (1995), A. Gül, unpub. data (2003), Sanders et al. (2004, 2014), Pickford et al. (2008). Mean values are available in Appendix 3. Colours indicate tooth type, symbols distinguish taxa. Only comparable tooth types are included in this diagram (e.g. incisors of Crivadiatherium or $\mathrm{p} 1$ of $A$. giganteum are not included). M1-M3 of Ph. fallax is highly damaged and lacks the measurements. L, length; W, width. $80 \times 39 \mathrm{~mm}(600 \times 600 \mathrm{DPI})$ 
Fig. 5. Strict consensus tree $(L=243$ steps, $C I=0.588$ and $R I=0.587)$ of ten shortest trees ( $L=237$ steps, $C I=0.603, R I=0.612$ ) obtained with PAUP 3.1 .1 based on 130 cranial and dental characters (character list and data matrix supplied in Appendices 1-2). Number of synapomorphies of each node is mentioned in italics, Bremer Indices in bold; node numbers in circle. $100 \times 62 \mathrm{~mm}(600 \times 600 \mathrm{DPI})$ 

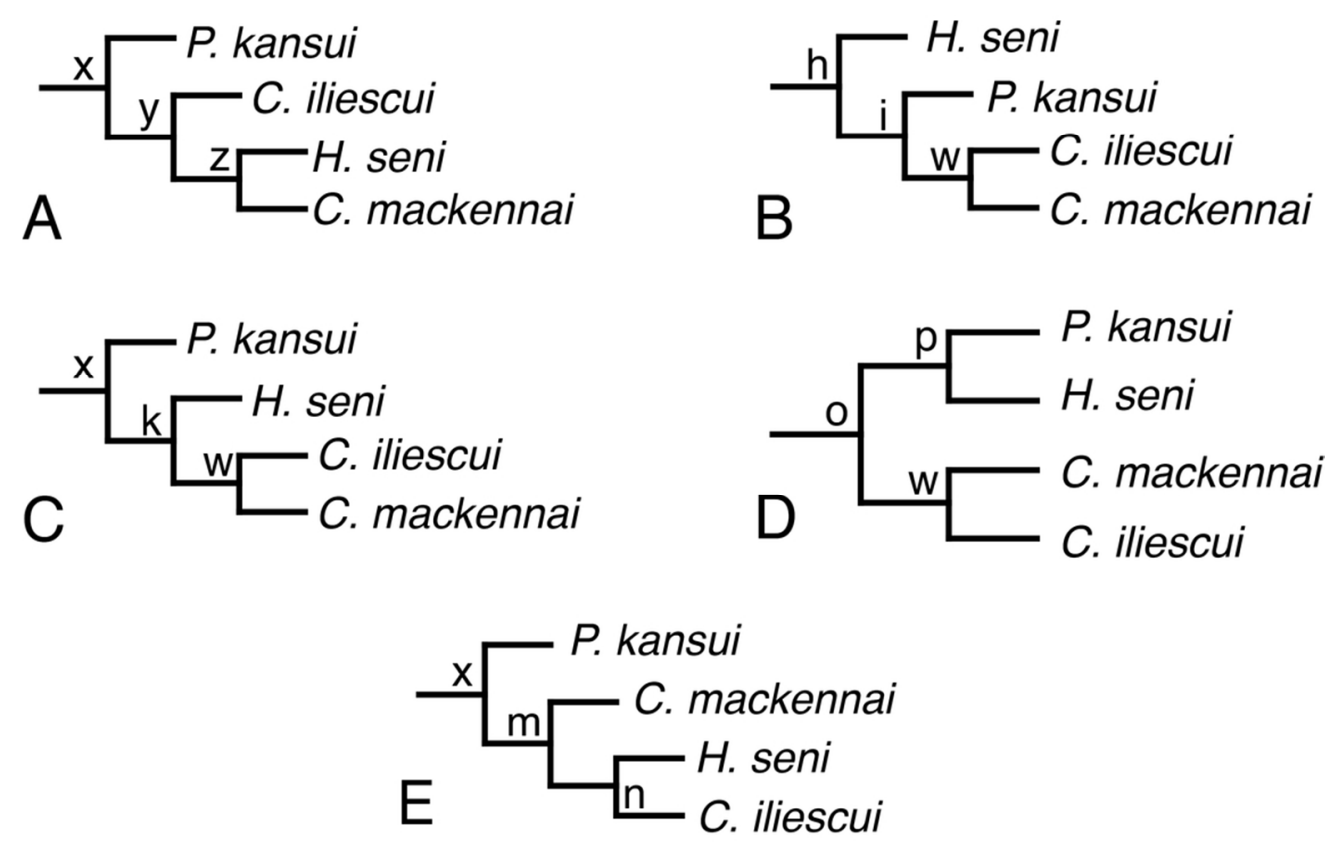

Fig. 6. Detail of the most parsimonious trees concerning Palaeoamasiinae ( $L=237$ steps, $C I=0.603$, $\mathrm{RI}=0.612$ ). Five alternative topologies of Eurasian embrithopods acquired by PAUP 3.1.1. The letters in lowercase indicate nodes. Note that nodes $\mathrm{x}$ and $\mathrm{w}$ reappear in different trees. $48 \times 31 \mathrm{~mm}(600 \times 600 \mathrm{DPI})$ 


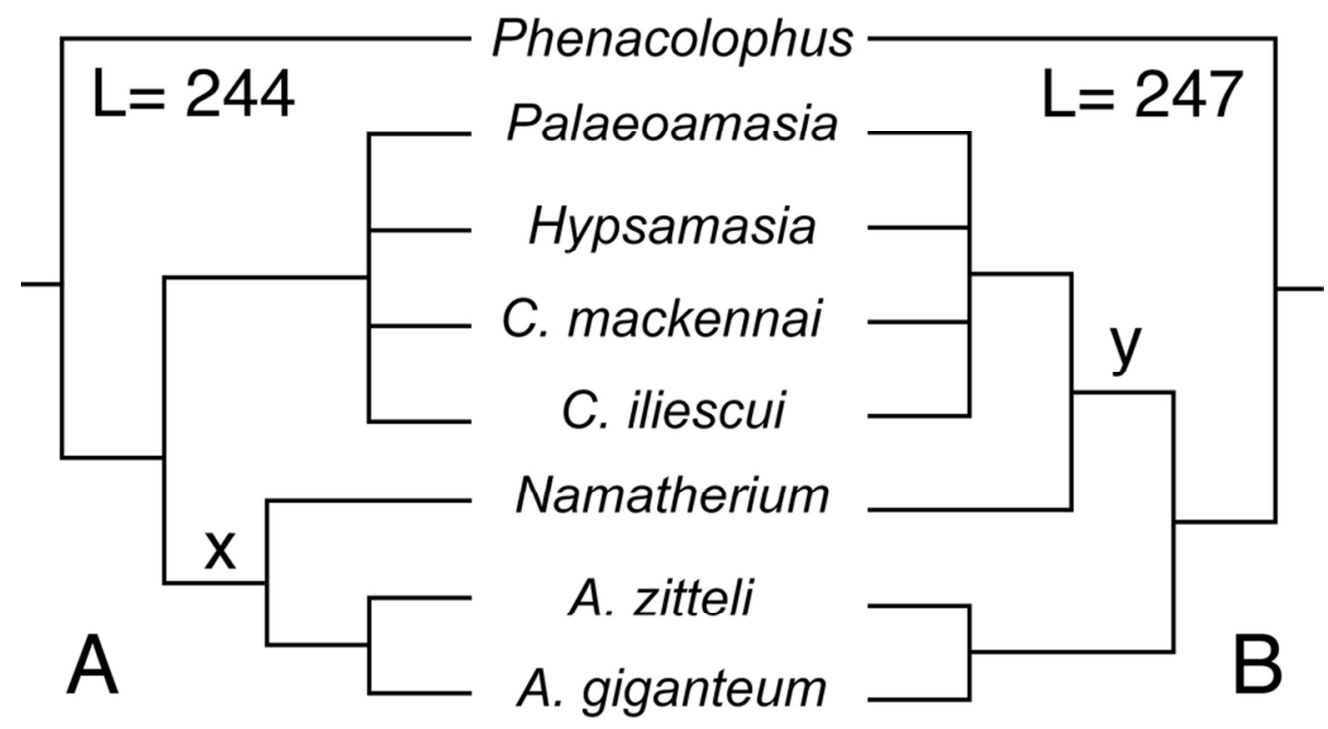

Fig. 7. Comparison of alternative topologies implying Namatherium. (A) Strict consensus $(L=244, C I=0.586$, $\mathrm{RI}=0.583$ ) of ten equally parsimonious trees with the node $\times$ (Namatherium+Arsinoitherium). (B) Strict consensus $(L=247, C I=0.579, R I=0.570)$ of ten equally parsimonious trees with the node $y$ (Namatherium+Palaeoamasiinae). L, branch length; $x$, three unambiguous synapomorphies; $y$, fourteen ambiguous synapomorphies. $43 \times 24 \mathrm{~mm}(600 \times 600 \mathrm{DPI})$ 


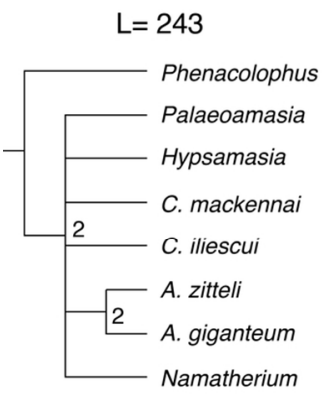

A

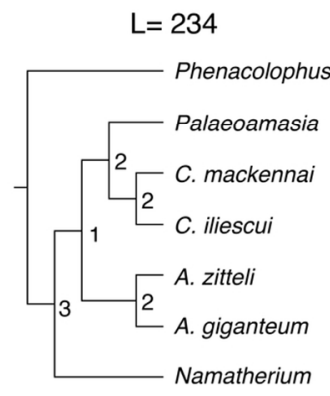

B

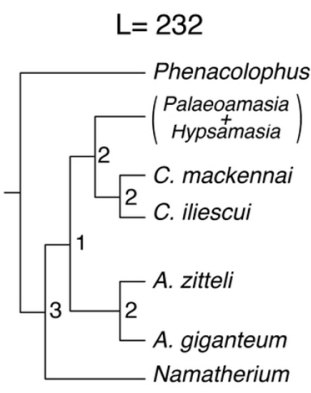

C

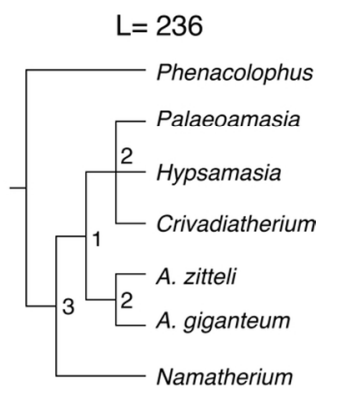

D

Fig. 8. Strict consensus tree topologies obtained by following different scenarii. Topology acquired ( $L=243$, $\mathrm{CI}=0.588, \mathrm{RI}=0.567)$ with exclusion of new specimens of Palaeoamasia kansui $(\mathrm{A})$; topology acquired $(\mathrm{L}=234, \mathrm{CI}=0.611, \mathrm{RI}=0.596)$ with exclusion of Hypsamasia seni $(B)$; topology acquired $(\mathrm{L}=232, \mathrm{CI}=0.612$, $\mathrm{RI}=0.598)$ under hypothesis of Palaeoamasia-Hypsamasia synonymy $(C)$; topology acquired $(\mathrm{L}=236$, $\mathrm{CI}=0.602, \mathrm{RI}=0.593$ ) where Crivadiatherium is terminal taxon (D). Numbers correspond to Bremer indices. $57 \times 20 \mathrm{~mm}(600 \times 600 \mathrm{DPI})$ 

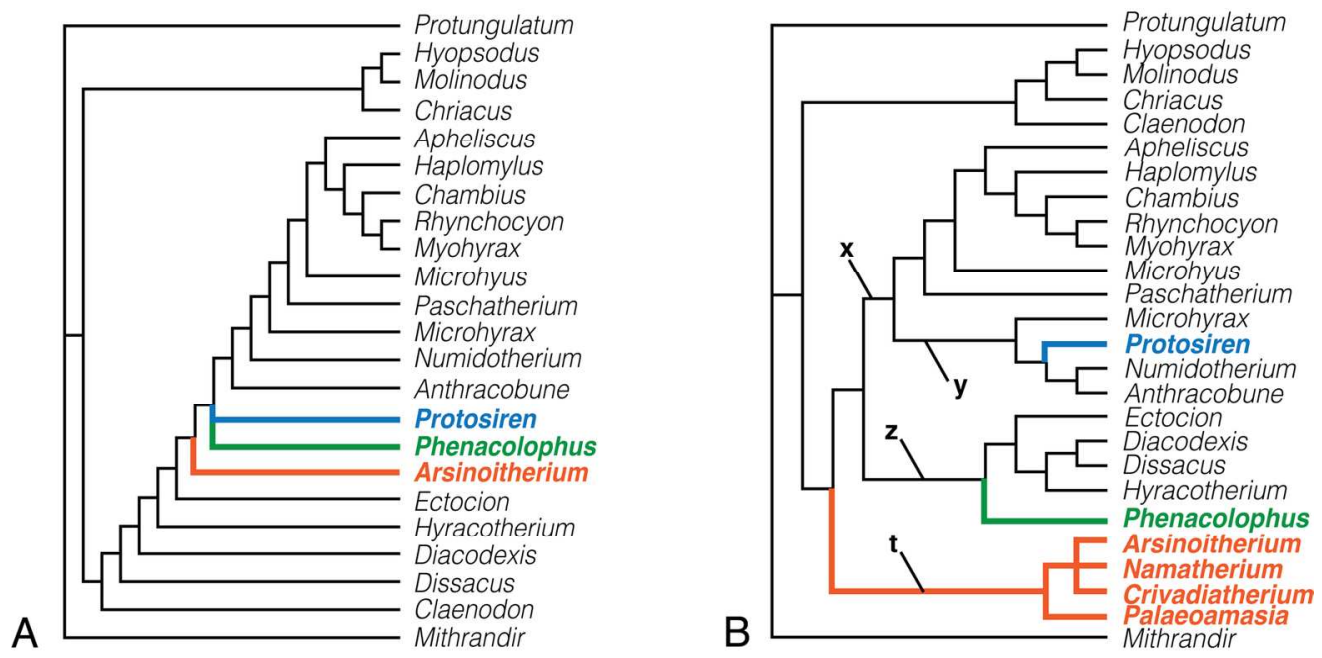

Fig. 9. Comparison of strict consensus trees established after successive weighting process following the data matrix of Tabuce et al. (2007). Topology published in Tabuce et al. (2007) (A; $L=49166, C I=0.43$,

$\mathrm{RI}=0.67$ ). Topology obtained with the same protocol after including other embrithopods such as Namatherium, Crivadiatherium and Palaeoamasia (B; $\mathrm{L}=47841, \mathrm{CI}=0.44, \mathrm{RI}=0.66)$. Lowercase letters indicate characters supporting the concerned node: two unambiguous postcranial characters $(x)$; three unambiguous postcranial characters $(y)$; two unambiguous postcranial characters $(z)$ and one unambiguous dental character (t) (Tabuce et al. 2007). $78 \times 39 \mathrm{~mm}(600 \times 600 \mathrm{DPI})$ 
1

2

3

4

5

6

7

8

9

10

11

12

13

14

15

16

17

18

19

20

21

22

23

24

25

26

27

28

29

30

31

32

33

34

35

36

37

38

39

40

41

42

43

44

45

46

47

48

49

50

51

52

53

54

55

56

57

58

59

60
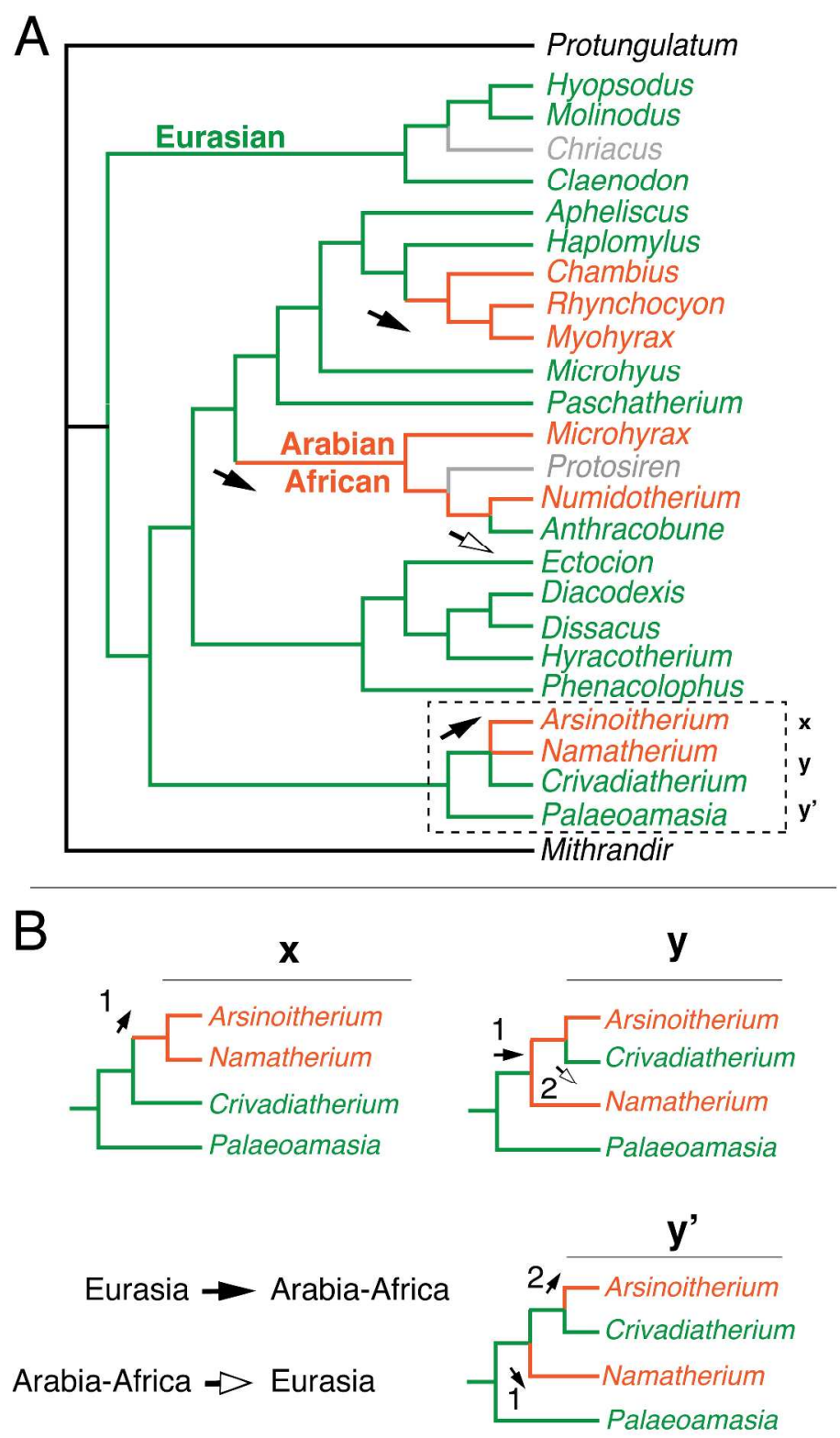

Fig. 10. Dispersal event hypothesis of Ungulata between Eurasia and Arabian-African continent. Topology displaying four dispersal events within Ungulata (modified after Tabuce et al. 2007) (A); Alternative topology concerning embrithopods illustrates three different dispersal events hypotheses (B). Green lines, Eurasian origin taxa; orange lines, Arabian-African origin taxa; grey lines, marine taxa; arrows, direction of migration. Lower case letters indicate different topologies with one ( $x$, parsimonious) or two dispersal events ( $y$ and $\left.y^{\prime}\right)$. $130 \times 225 \mathrm{~mm}(600 \times 600 \mathrm{DPI})$ 

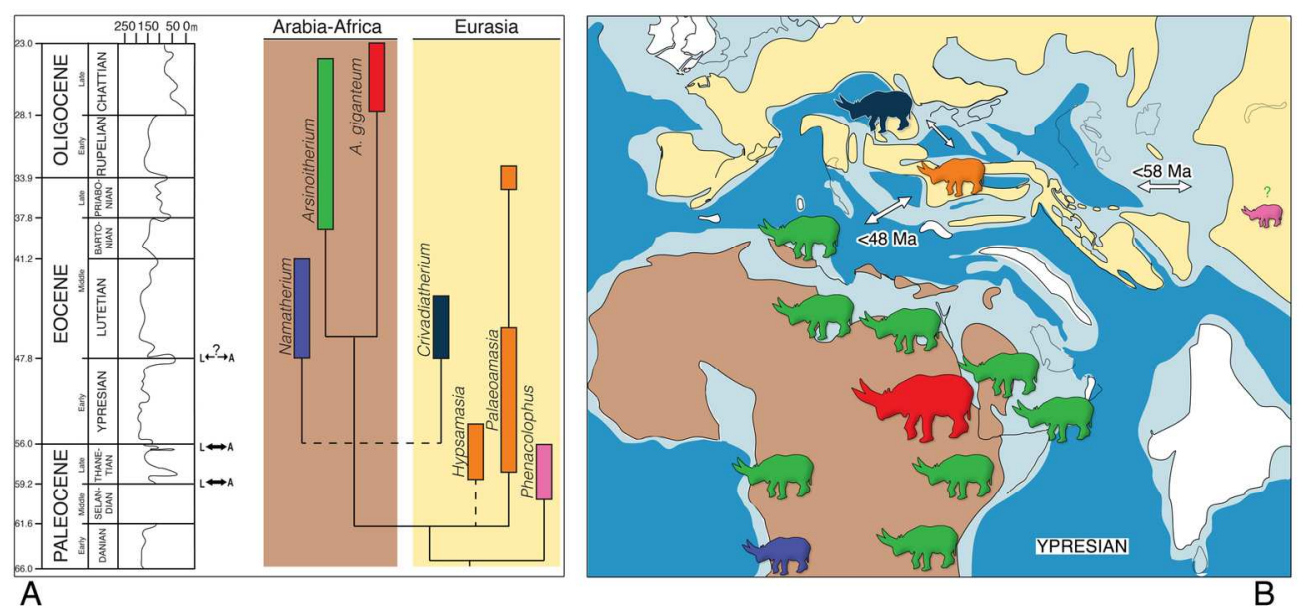

Fig. 11. Stratigraphical and palaeogeographical distribution of embrithopods in a phylogenetic framework (A). Distribution and hypothetical dispersal events for embrithopods (B). Colour codes on the map equal those of the phylogenetic tree in A. Palaeogeographical map at Ypresian times is modified after Barrier \& Vrielynck (2008) and Sen (2013). Geological time scale is modified after International Stratigraphic Chart (2015/1). Eustatic curve is modified after Gheerbrant \& Rage (2006). Arrows display possible faunal exchange events between Eurasia and Afro-Arabia. $78 \times 36 \mathrm{~mm}(600 \times 600 \mathrm{DPI})$ 
Table 1. List of embrithopods (and Phenacolophus fallax) in stratigraphical order with corresponding localities, time interval, authors and locality numbers given in Figure 1.

\begin{tabular}{|c|c|c|c|c|}
\hline Species & Locality & Age & Authors \& Date & $\begin{array}{l}\text { Localities in } \\
\text { Fig. } 1\end{array}$ \\
\hline Arsinoitherium $\mathrm{sp}$. & Lothidok (Kenya) & latest Oligocene & $\begin{array}{l}\text { Boschetto et al. } \\
\text { 1992; Rasmussen } \\
\text { \& Guiterrez } 2009\end{array}$ & 13 \\
\hline $\begin{array}{l}\text { Arsinoitherium } \\
\text { giganteum }\end{array}$ & Chilga (Ethiopia) & late Oligocene & $\begin{array}{l}\text { Sanders et al. } \\
\text { 2004; Kappelman } \\
\text { et al. } 2003\end{array}$ & 12 \\
\hline $\begin{array}{l}\text { Arsinoitherium } \mathrm{cf} . \\
\text { zitteli }\end{array}$ & $\begin{array}{c}\text { Shumaysi formation - Harrat Al } \\
\text { Ujayfa (Saudi Arabia) }\end{array}$ & early late Oligocene & $\begin{array}{l}\text { Zalmout et al. } \\
2010\end{array}$ & 11 \\
\hline Arsinoitherium sp. & Malembo - Cabinda (Angola) & early Oligocene & Pickford 1986 & 10 \\
\hline $\begin{array}{l}\text { Arsinoitherium zitteli } \\
\text { Beadnell, } 1902\end{array}$ & $\begin{array}{l}\text { Jebel Qatrani Formation - Fayoum } \\
\text { (Egypt) }\end{array}$ & early Oligocene (Seiffert 2006) & $\begin{array}{l}\text { Andrews et al. } \\
1906\end{array}$ & 9 \\
\hline $\begin{array}{l}\text { Embrithopoda cf. } \\
\text { Arsinoitherium }\end{array}$ & $\begin{array}{c}\text { Ashawq- Taqah Formation - } \\
\text { Dhofar (Oman) }\end{array}$ & early Oligocene (Seiffert 2006) & Thomas et al. 1999 & 8 \\
\hline Arsinoitherium sp. & $\begin{array}{c}\text { Ashawq Formation - Thaytiniti - } \\
\text { Dhofar (Oman) }\end{array}$ & earliest Oligocene (Seiffert 2006) & Thomas et al. 1989 & 8 \\
\hline Palaeoamasia sp. & $\begin{array}{c}\text { Cemalettin Formation, Boyabat- } \\
\text { Sinop (Turkey) }\end{array}$ & Eocene-Oligocene transition & Sanders et al. 2014 & $3 a$ \\
\hline Arsinoitherium sp. & $\begin{array}{c}\text { Aydim Formation - Dhofar } \\
\text { (Oman) }\end{array}$ & late Eocene (Bartonian-Priabonian) & $\begin{array}{l}\text { Al-Sayigh et al. } \\
2007\end{array}$ & 8 \\
\hline Arsinoitherium sp. & Dor el Talha (Libya) & early Oligocene & $\begin{array}{l}\text { Wight 1980; } \\
\text { Rasmussen et al. } \\
2008\end{array}$ & 7 \\
\hline Arsinoitherium sp. & Oued el Grigema (Tunisia) & late Eocene & Vialle et al 2013 & 6 \\
\hline $\begin{array}{l}\text { Namatherium } \\
\text { blackcrowense }\end{array}$ & $\begin{array}{c}\text { Black Crow - Sperrgebiet } \\
\text { (Namibia) }\end{array}$ & middle Eocene (Lutetian) & $\begin{array}{l}\text { Pickford et al. } \\
2008\end{array}$ & 5 \\
\hline $\begin{array}{l}\text { Crivadiatherium } \\
\text { mackennai }\end{array}$ & Depression of Hateg (Romania) & $\begin{array}{l}\text { middle Eocene (Radulesco \& Samson } \\
\text { 1987) }\end{array}$ & $\begin{array}{l}\text { Radulesco et al. } \\
1976\end{array}$ & 4 \\
\hline $\begin{array}{l}\text { Crivadiatherium } \\
\text { iliescui }\end{array}$ & Depression of Hateg (Romania) & $\begin{array}{l}\text { middle Eocene (Radulesco \& Samson } \\
\text { 1987) }\end{array}$ & $\begin{array}{c}\text { Radulesco \& } \\
\text { Sudre } 1985\end{array}$ & 4 \\
\hline $\begin{array}{l}\text { Palaeoamasia kansui } \\
\text { Ozansoy } 1966\end{array}$ & $\begin{array}{c}\text { Boyabat - Sinop ; Çiçekdağı - } \\
\text { Kirsehir ; Bultu-Zile - Tokat; } \\
\text { Boğazliyan-YeniFakili - } \\
\text { Yozgat (Turkey) }\end{array}$ & early Eocene to middle Eocene & $\begin{array}{l}\text { Ozansoy 1966; } \\
\text { Sen \& Heintz } \\
\text { 1979; Kaya } 1995\end{array}$ & $3 a, c, d, e$ \\
\hline $\begin{array}{l}\text { Palaeoamasia kansui } \\
\text { Ozansoy } 1966\end{array}$ & Eski-Çeltek - Amasya (Turkey) & $\begin{array}{c}\text { early Eocene (Koc \& Turkmen 2002; } \\
\text { Métais et al. 2012) } \\
\text { late Paleocene (Kazanci \& Gökten }\end{array}$ & Sen \& Heintz 1979 & $3 b$ \\
\hline Palaeoamasia sp. & $\begin{array}{c}\text { Uzunçarşıdere Formation - } \\
\text { Haymana-Polatlı Bassin (Turkey) }\end{array}$ & $\begin{array}{l}\text { 1986; Ladevèze et al. 2010) or early } \\
\text { Eocene (Kappelman et al. 1996; Maas } \\
\text { et al. 1998; Maas et al. 2001) }\end{array}$ & Gül 2003 & $3 f$ \\
\hline Hypsamasia seni & $\begin{array}{c}\text { Uzunçarşıdere Formation - } \\
\text { Haymana-Polatlı Bassin (Turkey) }\end{array}$ & $\begin{array}{l}\text { late Paleocene (Kazanci \& Gökten } \\
\text { 1986; Ladevèze } \text { et al. 2010) or early } \\
\text { Eocene (Maas et al. 1998) }\end{array}$ & Maas et al. 1998 & 2 \\
\hline Phenacolophus fallax & Gashato Formation (Mongolia) & late Paleocene - early Eocene & $\begin{array}{c}\text { Matthew \& } \\
\text { Granger 1925; } \\
\text { McKenna \& } \\
\text { Manning } 1977\end{array}$ & 1 \\
\hline
\end{tabular}


Table 2. Interordinal classification of Embrithopoda (parenthetical mode) according to previous authors.

\begin{tabular}{|c|c|}
\hline Simpson 1945 & $\begin{array}{l}\text { Paenungulata: (Proboscidea, Hyracoidea, Embrithopoda, Pantodonta, Pyrotheria, Dinocerata, } \\
\text { (Sirenia +Desmostyliformes)) }\end{array}$ \\
\hline McKenna 1975 & $\begin{array}{l}\text { Ungulata: (Arctocyona, Tillodontia, Tubulidentata, Dinocerata, Embrithopoda, Artiodactyla), } \\
\text { (Condylarthra, Perissodactyla, Hyracoidea), (Tethytheria: (Proboscidea, Sirenia, Desmostylia)) }\end{array}$ \\
\hline Novacek 1986 & $\begin{array}{l}\text { Ungulata: (Arctocyonia, Dinocerata, Embrithopoda, Artiodactyla, Cetacea, Perissodactyla), } \\
\text { (Paenungulata: (Hyracoidea, Proboscidea, Sirenia, Desmostylia)) }\end{array}$ \\
\hline Court $1992 b, 1992 c$ & (Sirenia,(Proboscidea, Embrithopoda)) \\
\hline Novacek \& Wyss 1986 & (Embrithopoda, Paenungulata) or (Embrithopoda, Tethytheria) \\
\hline McKenna \& Bell 1997 & Uranotheria: (Hyracoidea, Embrithopoda, Tethytheria: (Sirenia, (Proboscidea + Desmostylia))) \\
\hline Gheerbrant et al. $2005 \mathrm{a}$ & $\begin{array}{l}\text { (Phenacolophus, Embrithopoda),(Minchenella, (Anthracobunidae, (Desmostylia, (Sirenia, } \\
\text { Proboscidea)))) }\end{array}$ \\
\hline Tabuce et al. 2007 & (Arsinoitherium,$($ Sirenia + Probosciea + Hyracoidea $))$ \\
\hline Seiffert 2007 & Paenungulata: (Tethytheria: (Proboscidea, (Arsinoitherium + Sirenia))), Hyracoidea) \\
\hline Gheerbrant 2009 & $\begin{array}{l}\text { (Hyracoidea, (Phenacolophus, (Embrithopoda, (Minchenella, (Anthracobunidae, (Desmostylia, } \\
\text { Sirenia), Proboscidea)))) }\end{array}$ \\
\hline Benoît et al. 2013 & (Sirenia, (Desmostylus, (Arsinoitherium, Proboscidea))) \\
\hline Gheerbrant et al. 2014 & $\begin{array}{l}((\text { Perissodactyla, Radinskya),(Hyracoidea, }(\text { Anthracobunia },((\text { Eritherium },(\text { Phosphatherium }, \\
\text { Numidotherium })),(\text { Desmostylia,(Sirenia,(Minchenella,(Phenacolophus, Embrithopoda })))))))\end{array}$ \\
\hline Cooper et al. 2014 & $\begin{array}{l}\text { ((Desmostylia, Anthracobunidae, Perissodactyla), (Afrotheria: (Paenungulata: } \\
(((\text { Embrithopoda, Sirenia), Phosphatherium, Proboscidea), Eritherium, Hyracocoidea)))) }\end{array}$ \\
\hline
\end{tabular}


1

2

3

4

5

6

7

8

9

10

11

12

13

14

15

16

17

18

19

20

21

22

23

24

25

26

27

28

29

30

31

32

33

34

35

36

37

38

39

40

41

42

43

44

45

46

47

48

49

50

51

52

53

54

55

56

57

58

59

60

Table 3. Dental measurements (in mm) of new material of Palaeoamasia kansui, and casts of Hypsamasia seni, Crivadiatherium mackennai and C. iliescui specimens.

\begin{tabular}{|c|c|c|c|c|}
\hline & $\begin{array}{l}\text { Institution } \\
\text { number }\end{array}$ & Length & $\begin{array}{l}\text { Mesial } \\
\text { width }\end{array}$ & $\begin{array}{l}\text { Distal } \\
\text { width }\end{array}$ \\
\hline \multicolumn{5}{|l|}{ P. kansui } \\
\hline Left P2 & ITU-EÇ-8 & 14.7 & 16.5 & - \\
\hline Left P3 & ITU-EÇ-8 & 16.2 & 18.7 & - \\
\hline Right P4 & ITU-EÇ-7 & - & 24.5 & - \\
\hline Right M1 & ITU-EÇ-7 & 23.8 & 30.4 & 31.4 \\
\hline Right M2 & ITU-EÇ-7 & 32.0 & 33.2 & 28.0 \\
\hline Left M3 & MNHN-EÇ-6 & 33.5 & - & 28.1 \\
\hline Left p2 & ITU-EÇ-9 & - & 8.1 & 7.8 \\
\hline Left $\mathrm{p} 3$ & ITU-EÇ-9 & 16.6 & 10.7 & 11.3 \\
\hline Right p4 & MNHN-EÇ-5 & - & 12.3 & - \\
\hline Left $\mathrm{p} 4$ & ITU-EÇ-9 & 16.9 & 12.1 & 11.5 \\
\hline Left $\mathrm{m} 1$ & ITU-EÇ-9 & - & 15.9 & 17.1 \\
\hline Right m1 & MNHN-EÇ-5 & 24.2 & 17.8 & 18.1 \\
\hline \multicolumn{5}{|l|}{ H. seni } \\
\hline Right P2 & AK95-52 & - & 17.0 & - \\
\hline Right P3 & AK95-52 & 18.0 & - & - \\
\hline Right P4 & AK95-52 & - & - & - \\
\hline Left M2 & AK95-52 & - & 39.9 & - \\
\hline \multicolumn{5}{|c|}{ C. mackennai } \\
\hline Left p4 & & 26.0 & 16.1 & 16.7 \\
\hline Left $\mathrm{m} 1$ & & 34.6 & 18.4 & 20.6 \\
\hline \multicolumn{5}{|l|}{ C. iliescui } \\
\hline Left p2 & & - & - & 16.1 \\
\hline Left p3 & & 25.3 & 18.0 & 18.8 \\
\hline Left $\mathrm{p} 4$ & & 28.0 & 18.5 & 19.2 \\
\hline Left $\mathrm{m} 2$ & & 46.8 & 25.2 & 26.9 \\
\hline Right $\mathrm{m} 2$ & & 45.9 & 26.9 & 26.3 \\
\hline Left m3 & & $>55.0$ & 26.0 & 26.2 \\
\hline
\end{tabular}


Table 4. List of unambiguous apomorphies on nodes of the strict consensus tree.

Synapomorphies : node 2 (Paenungulata) : 18(1), 29(1), 30(1), 38(1), 39(1), 40(1), 53(1 or 2), 54(1), 59(1), 75(1), 79(0), 87(0) ; node 3 (Proboscidea + Seggeurius) : 45(1), 99(0); node 4 (Proboscidea) : 46(0), 49(1), 55(0), 80(1), 106(3), 108(1), 117(1), 127(1) ; node 5 (Embrithopoda sensu lato) : 11(1), 51(0), 65(0), 69(0), 70(0), 72(1), 114(0), 126(1), 128(1); node

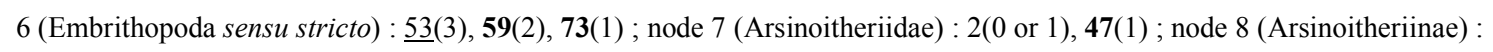
44(1), 83(1), 102(1), 116(1); node 9 (Palaeoamasiinae) : 20(1), 106(0), 115(0).

Autapomorphies : Seggeurius amourensis : 23(0), 86(0); Eritherium azzouzorum : 32(0); Phosphatherium escuilliei :

70(2); Phenacolophus fallax : 27(1), 77(1), 93(0), 110(0); Namatherium blackcrowense : 13(1); Arsinoitherium zitteli : not any character unambiguous; Arsinoitherium giganteum : not any character unambiguous; Palaeoamasia kansui : 37(1), 103(1); Hypsamasia seni : not any character unambiguous; Crivadiatherium mackennai : 124(0); Crivadiatherium iliescui : $129(0), 130(0)$.

Unambiguous and non-homoplastic characters are in bold, unambiguous autapomorphies of which corresponding state is not homoplastic are in italics and unambiguous and weakly homoplastic characters $(0.75 \leq \mathrm{RI}<1)$ are underlined. Homoplastic characters $(\mathrm{RI}<0.75)$ lack any annotations. Each character state is mentioned in brackets. Ambiguous characters are excluded from that list. Complete distribution of characters is in Appendix 4. 
1

2

3

4

5

6

7

8

9

10

11

12

13

14

15

16

17

18

19

20

21

22

23

24

25

26

27

28

29

30

31

32

33

34

35

36

37

38

39

40

41

42

43

44

45

46

47

48

49

50

51

52

53

54

55

56

57

58

59

60

Table 5. Number of characters scored for Arsinoitherium, Palaeoamasia, Namatherium, Crivadiatherium and Hypsamasia species depending on available specimens.

\begin{tabular}{lllll}
\hline Taxa $\backslash$ Characters & $\begin{array}{l}\text { Cranial- } \\
\text { mandibular } \\
(/ 10)\end{array}$ & $\begin{array}{l}\text { Upper } \\
\text { dentition } \\
(/ 63)\end{array}$ & $\begin{array}{l}\text { Lower } \\
\text { dentition } \\
(/ 57)\end{array}$ & $\begin{array}{l}\text { Total } \\
(/ 130)\end{array}$ \\
\hline A. zitteli & 10 & 55 & 54 & 119 \\
P. kansui & 6 & 62 & 51 & 119 \\
N. blackcrowense & 4 & 49 & 0 & 53 \\
C. iliescui & 0 & 0 & 51 & 51 \\
A. giganteum & 1 & 12 & 36 & 49 \\
H. seni & 0 & 49 & 0 & 49 \\
C. mackennai & 0 & 0 & 40 & 40 \\
\hline
\end{tabular}

Numbers in bracket present the total number of characters available on concerning anatomical parts. 


\title{
APPENDIX S1. LIST OF CRANIAL AND DENTAL CHARACTERS USED IN THE CLADISTIC ANALYSIS
}

\begin{abstract}
N.B. Characters chosen from literature are mentioned in brackets; asterisk $\left(^{*}\right)$ indicates new characters, not used in any previous phylogenetic analysis; char., characters; (o), ordered character states.
\end{abstract}

\section{Cranial-mandibular characters}

1- Zygomatic arch shape : (0) Poorly divergent laterally ; (1) Widely divergent laterally (char. 21 in Gheerbrant et al. 2005 and char. 130 in Gheerbrant 2009)

2- *Zygomatic arch, position of zygomatic process (distal side in ventral view) (o) : (0) Begins at distal loph level of M3 ; (1) Begins at mesial loph level of M3 ; (2) Begins at level of M2-P4. (Sen \& Heintz 1979 ; Court 1992c ; Pickford et al. 2008)

3- Zygomatic process of the squamosal : (0) Reduced ; (1) Strong (char. 23 of Gheerbrant et al. 2005 and char. 132 of Gheerbrant 2009)

4- Mandibular symphysis, distal edge : (0) At level of premolar ; (1) At level of molar (char. 38 modified after Gheerbrant et al. 2005 and char. 46 in Gheerbrant, 2009)

5- Mandibular symphysis, connection : (0) Unfused ; (1) Fused (char. 47 in Gheerbrant 2009)

6- Mandibular symphysis, orientation in lateral view : (0) Oblique ; (1) (Sub-)vertical (McKenna \& Manning 1977)

7- Horizontal ramus : (0) Low; (1) High (char. 40 in Gheerbrant et al. 2005 and char. 48 in Gheerbrant, 2009)

8- *Angular discontinuity of mandible between premolars and molars in lateral view : (0) Absent ; (1) Present (Court 1992b) 
9- Skull shape : (0) Rostrum > basicranium ; (1) Rostrum $\leq$ basicranium (Froehlich 2002 ; char. 109 in Gheerbrant 2009)

10- Tuber maxillae, development: (0) Reduced or absent ; (1) Wide (char. 122 modified after Gheerbrant 2009)

Dental characters

11- Dental dimensions : (0) Small ; (1) Large (char. 46 in Gheerbrant et al. 2005)

Upper teeth

12- Upper premolars, molarization : (0) Absent ; (1) molarized P4 and/or P3 (McKenna \& Manning 1977)

13- *Upper premolars, lingual cingulum : (0) Absent ; (1) Present

14- *Upper premolars, mesial cingulum : (0) Present; (1) Absent (Sen \& Heintz 1979)

15- *Upper premolars, distal cingulum : (0) Present; (1) Absent (Sen \& Heintz 1979)

16- *Upper premolars, labial cingulum : (0) Present; (1) Absent

17- *Upper premolars, junction of postprotocrista/distal cingulum :(0) Absent ; (1) Present (Maas et al, 1998)

18- *Upper premolars, postprotocrista orientation : (0) Oriented rather disto-labially (towards metacone) ; (1) Oriented rather mesio-distally

19- *Upper premolars, height of root / crown : (0) $0 \geq 1$; (1) $0<1$ (Sen \& Heintz 1979)

20- P2, number of root : (0) Two-rooted ; (1) Three-rooted ; (2) One-rooted (char. 99 modified after Gheerbrant et al. 2005)

21- P2, protocone : (0) Present; (1) Absent (char. 100 modified after Gheerbrant et al. 2005) 
22- *P2, preprotocrista and protocone : (0) Form a mesio-lingually convex crista ; (1)

Form a straight crista

23- P2, metacone : (0) Absent ; (1) Present (char. 104 modified after Gheerbrant et al. 2005)

24- *P2, labial side : (0) Smooth ; (1) Undulated

25- *P2, mesio-distal valley : (0) Narrow (wide ectoloph) ; (1) Wide (narrow ectoloph)

26- *P2-P3, ectoloph : (0) Present ; (1) Absent (Sen \& Heintz 1979)

27- P3, protocone : (0) Present; (1) Absent or reduced (char. 101 in Gheerbrant et al. 2005)

28- *P3, number of roots : (0) Two-rooted ; (1) Three-rooted (char. 68 modified after Gheerbrant 2009)

29- P3, paraconule : (0) Present ; (1) Absent (char. 23 in Froehlich 2002)

30- P3, metaconule : (0) Present ; (1) Absent (Maas et al. 1998 ; char. 30 in Froehlich 2002)

31- P3, postprotocrista: (0) Absent ; (1) Present (char. 27 in Froehlich 2002)

32- P3, metacone : (0) Absent ; (1) Present (char. 70 modified after Gheerbrant, 2009)

33- P3, metacone : (0) Smaller than paracone ; (1) Similar size (char. 70 modified after Gheerbrant 2009)

34- *P2-4, hypocone : (0) Absent; (1) Present (char. 108 modified after Gheerbrant et al. 2005)

35- *P3-4, paracone and protocone : (0) Joined by a preprotocrista ; (1) Disjoined (Sen \& Heintz 1979)

36- *P3, preprotocrista / postprotocrista, length proportion : (0) Preprotocrista > postprotocrista ; (1) Preprotocrista $\leq$ postprotocrista (Maas et al.1998)

37- *P4, preprotocrista / postprotocrista, length proportion : (0) Preprotocrista > postprotocrista ; (1) Preprotocrista $\leq$ postprotocrista (Maas et al.1998) 
38- P4, paraconule : (0) Present ; (1) Absent (Maas et al. 1998 ; char. 31 in Froehlich 2002)

39- P4, metaconule : (0) Present ; (1) Absent (Maas et al. 1998 ; char. 33 in Froehlich 2002)

40- P4, postprotocrista : (0) Present ; (1) Absent (char. 35 in Froehlich 2002)

41- *P4/M1, proportion of dimensions : (0) P4 $\approx$ M1 ; (1) P4 < M1 (Sen \& Heintz 1979)

42- *Upper Molars, root / crown height proportion : (0) >1 ; (1) <1 (Sen \& Heintz 1979)

43- Upper Molars, lingual cingulum : (0) Absent ; (1) Present (char. 121 de Gheerbrant et al. 2005)

44- *Upper Molars, distal cingulum: (0) Present ; (1) Absent (Sen \& Heintz 1979)

45- Upper Molars, distocrista (=posthypocrista) : (0) Absent ; (1) Present (at least on M12) (char. 99 in Gheerbrant 2009)

46- Upper Molars, distal cingulum (shape and connection) (o) : (0) Distal cingulum (=postcingulum) in continuity with the hypocone via the distocrista ; (1) Distal cingulum extended lingually below the hypocone ; (2) Distal cingulum extended lingually below the hypocone and linked to a lingual cingulum (char. 86 in Gheerbrant 2009)

47- *Upper Molars, labial cingulum (ectocingulum sensu Froehlich 2002) : (0) Present ; (1) Absent

48- Upper Molars, parastyle position : (0) Labial to the paracone ; (1) Mesial (modified after of char. 110 in Gheerbrant et al. 2005 and char. 82 in Gheerbrant 2009)

49- Upper Molars, preparacrista : (0) Present ; (1) Absent (char. 93 modified after Gheerbrant 2009)

50- Upper Molars, preparacrista : (0) Well developed and distinct ; (1) Small (reduced) (char. 93 modified after Gheerbrant 2009) 
51- Upper Molars, preparacrista orientation : (0) Rather transversal ; (1) Rather sagittal (char. 93 modified after Gheerbrant 2009)

52- *Upper Molars (and dP4), postparacrista (sensu Maas et al. 1998) : (0) Distinct ; (1) Reduced or absent (char. 112 in Gheerbrant et al. 2005)

53- Upper Molars, shape of postparacrista (o) : (0) Rectodont and not linked to mesostyle ; (1) Linked to the lingual flank of the mesostyle and nearly rectodont ; (2) Extensively linked to the mesostyle and noticeably dilambdodont ; (3) Lingual migration of paracone and metacone with the postparacrista hyper-dilambdodont (char. 91 in Gheerbrant 2009)

54- Upper Molars, mesostyle development : (0) Reduced or absent ; (1) Developed and well distinct (char. 113 in Gheerbrant et al. 2005)

55- Upper Molars, mesostyle position : (0) Close to paracone and metacone ; (1) Shifted labially (char. 89 modified after Gheerbrant 2009)

56- Upper Molars, conules : (0) Present ; (1) Absent or obviously reduced (car. 114 de Gheerbrant et al. 2005)

57- Upper Molars, postprotocrista : (0) Present ; (1) Absent (char. 119 modified after Gheerbrant et al. 2005)

58- Upper Molars, lingual roots : (0) Endowed with a vertical median groove ; (1) Divided (char. 122 modified after Gheerbrant et al. 2005)

59- Upper Molars, structural plan (o) : (0) Rectodont ; (1) Dilambdodont ; (2) Hyperdilambdodont ['pseudolophodonty'] (char. 124 in Gheerbrant et al. 2005)

60- Upper Molars, structural plan : (0) Bunodont-lophodont ; (1) True lophodont [nonapplicable on taxa bearing 'pseudolophodonts' teeth] (char. 125 modified after Gheerbrant et al. 2005 and char. 80 modified after Gheerbrant 2009)

61- *Upper Molars, ectoloph : (0) Present ; (1) Absent (Sen \& Heintz 1979) 
62- *Upper Molars, labial / lingual height proportion : (0) Higher ; (1) Lower or equal (« unilateral hypsodonty » sensu Radulesco et al. 1976) (Sen \& Heintz 1979)

63- Upper Molars, postmetacrista (metastyle sensu Froehlich 2002) : (0) Present ; (1) Absent (Court 1992b ; char. 92 in Gheerbrant 2009)

64- Upper Molars, postmetacrista : (0) Developed ; (1) Reduced (Court 1992b ; char. 92 in Gheerbrant 2009)

65- Upper Molars, postmetacrista orientation : (0) Labio-lingual ; (1) Mesio-distal (Court 1992b ; char. 92 in Gheerbrant 2009)

66- Upper Molars, loph orientation (or pseudolophs) in occlusal view : (0) Distolingually oblique ; (1) Transverse (Court 1992b ; char. 120 in Gheerbrant et al. 2005)

67- *Upper Molars, lophs wear surfaces (or pseudolophs) in lateral view : (0) Merged with occlusal plan; (1) Mesio-ventrally inclined (Sen \& Heintz 1979 ; Pickford et al. 2008)

68- Upper Molars, relative size : (0) M3 < M2 ; (1) M3 $\geq$ M2 (Sen \& Heintz 1979 ; char. 123 modified after Gheerbrant et al. 2005)

69- Upper Molars, prehypocrista : (0) Absent ; (1) Present (char. 97 in Gheerbrant 2009)

70- Upper Molars, metaloph : (0) Formed by transversal alignment of hypocone, metaconule (if present) and metacone ; (1) Formed principally by a prehypocrista which joins the metaconule or the base of metacone ; (2) Formed by a prehypocrista which joins the apex of metacone (true lophodonty) (char. 97 modified after Gheerbrant 2009)

71- *M3, mesio-lingual angle : (0) Mesial and lingual cingulums continuous ; (1) Mesial and lingual cingulums discontinuous

72- *Upper teeth row, width (o) : (0) Increase progressively from P2 to M3 (although M3 is variable); (1) Increase progressively from P2 to M2, M3 is clearly larger ; (2) 
Increase progressively from $\mathrm{P} 2$ to $\mathrm{M} 1, \mathrm{M} 2$ and $\mathrm{M} 3$ are clearly larger (Pickford et al. 2008)

73- Crown height : (0) Crown uniformly brachyodont ; (1) Lingual and/or labial hypsodonty (char. 106 in Gheerbrant 2009)

Lower teeth

74- Lower incisors, orientation : (0) Sub-vertical ; (1) Antero-posteriorly inclined (char. 48 in Gheerbrant et al. 2005)

75- Lower incisors, absolute size : (0) Small ; (1) Medium to large (char. 49 in Gheerbrant et al. 2005)

76- Lower incisors, relative size of i1 : (0) i1 $\leq \mathrm{i} 2$; (1) i1 > i2 (char. 50 in Gheerbrant et al. 2005 ; char. 3 in Gheerbrant 2009)

77- Lower incisors, relative size of i3 : (0) i3 $\leq$ i2 ; (1) i3 > i2 (char. 5 modified after Gheerbrant 2009)

78- Lower canine : (0) Incisiform ; (1) Caniniform (Court, 1992b ; McKenna \& Manning, 1977)

79- Lower dentition, c-p diastema [(d)p1 or p2] : (0) Absent ; (1) Present (modified after char. 55 in Gheerbrant et al. 2005 and char. 8 in Gheerbrant 2009)

80- Lower premolars, paraconid : (0) Present ; (1) Absent or weak (char. 64 modified after Gheerbrant et al. 2005)

81- Lower premolars, paraconid (position) : (0) Low ; (1) High (char. 63 in Gheerbrant et al. 2005)

82- *Lower premolars, labial groove in labial view : (0) Vertical ; (1) Mesio-dorsally oblique 
83- *p2-p3, trigonid and talonid (height) in lateral view : (0) Trigonid > talonid ; (1) Trigonid $\approx$ talonid (Radulesco \& Sudre 1985)

84- Lower premolars, labial cingulid : (0) Present ; (1) Absent (char. 68 modified after Gheerbrant et al. 2005)

85- *Lower premolars, lingual cingulid : (0) Present ; (1) Absent (Sen \& Heintz 1979)

86- (d)p1 : (0) Two-rooted; (1) One-rooted (char. 57 modified after Gheerbrant et al. 2005 ; char. 10 in Gheerbrant 2009)

87- *Diastema between (d)p1 et p2 : (0) Absent ; (1) Present

88- p2 : (0) Two-rooted ; (1) One-rooted (char. 59 in Gheerbrant et al. 2005)

89- p3, molarization : (0) Absent ; (1) Present (char. 61 modified after Gheerbrant et al. 2005)

90- p3, hypoconid : (0) Absent ; (1) Present (McKenna \& Manning 1977)

91- *p3, metaconid position : (0) Integrated into mesio-distal row ; (1) Lingually isolated and forms a notch (Court, 1992b)

92- p4, molarization : (0) Absent ; (1) Present (char. 61 modified after Gheerbrant et al. 2005)

93- *p4, metaconid position : (0) Integrated into mesio-distal row ; (1) Lingually isolated and forms a notch (Court 1992b)

94- p4, mesostylid : (0) Metaconid lacks mesostylid ; (1) Metaconid possess a mesostylid (McKenna \& Manning 1977)

95- *p4, lingual fossettid in occlusal view : (0) Distal fossettid more developed mesiodistally in comparison to mesial fossettid ; (1) Distal fossettid less developed mesiodistally in comparison to mesial fossettid (Radulesco et al. 1976 ; Sen \& Heintz 1979 ; Court 1992b)

96- *p4, distal lingual fossettid in lingual view : (0) in ' $V$ ' shape ; (1) in ' $U$ ' shape 
97- p4, mesial cingulid : (0) Present ; (1) Absent (McKenna \& Manning 1977)

98- *p4, distal cingulid : (0) Present ; (1) Absent (McKenna \& Manning 1977)

99- p4, talonid development : (0) Reduced ; (1) Enlarged (char. 19 in Gheerbrant 2009)

100-p4 : (0) Non-bilophodont (protocristid oblique, hypolophid absent) ; (1) sub-lophodont (transversal protocristid, differentiated hypolophid) (char. 65 of Gheerbrant et al. 2005)

101-*p4, trigonid and talonid (height) lateral view : (0) Trigonid > talonid ; (1) Trigonid $\approx$ talonid (Radulesco \& Sudre 1985)

102-*Lower molars, mesial cingulid : (0) Present ; (1) Absent (Radulesco \& Sudre 1985)

103-*Lower molars, mesial cingulid (development) : (0) Strong, forms a fossette on mesiobuccal angle; (1) Weakly developed

104-*Lower molars, distal cingulid (development) : (0) Not elevated ; (1) Lingually elevated

105-Lower molars, mesostylid : (0) Present ; (1) Weak to absent (McKenna \& Manning 1977)

106-Lower molars, orientation of cristid oblique in occlusal view (o) : (0) Noticeably oblique, mesial ending in the lingual half of trigonid where it is extended towards apex of metaconid ; (1) Cristid oblique is extended towards the base of metaconid ; (2) Mesial ending of cristid oblique is at half of width on the distal flank of trigonid ; (3) Cristid oblique is weakly oblique, mesial ending at labial half of trigonid (char. 69 modified after Gheerbrant et al. 2005 ; McKenna \& Manning 1977)

107-Lower molars, entocristid : (0) Present ; (1) Absent (char. 71 modified after Gheerbrant et al. 2005)

108-Lower molars, premetacristid : (0) Reduced to absent ; (1) Distinct (char. 72 in Gheerbrant et al. 2005) 
109-Lower molars, postmetacristid : (0) Absent or well reduced ; (1) Distinct and more or less rounded into the metastylid (char. 73 in Gheerbrant et al. 2005)

110-Lower molars, paraconid : (0) Present ; (1) Absent (fused into paralophid) (char. 74 in Gheerbrant et al. 2005)

111-Lower molars, trigonid and paracristid (paralophid) : (0) Trigonid is more or less mesio-distally flared with a more developed and functional paracristid ; (1) Trigonid is short, noticeably constrict mesio-distally, paracristid reduced (char. 75 in Gheerbrant et al. 2005)

112-Lower molars, protocristid : (0) Protocristid bearing a remarkable median notch ; (1) Protocristid lophoid (=protolophid), cristid high and sub-continuous (char. 76 in Gheerbrant et al. 2005)

113-Lower molars, distal lophid (hypolophid) - postcristid complex : Hypolophid incomplete or composite, formed by an entolophid in continuity with labial segment of postcristid which is shifted anterior to the hypoconulid ; (1) Hypolophid sub-complete but bears a strong median notch ; (2) Hypocristid lophoid (high and sub-continuous from the apex of entoconid towards hypoconid) (char. 79 modified after Gheerbrant $e t$ al. 2005)

114-Lower molars, appearance of lophids : (0) Lophids oblique in comparison to the transversal axis ; (1) Lophids obviously transversal (char. 85 in Gheerbrant et al. 2005) 115- *Lower molars, cristid oblique : (0) High (at the level of occlusal surface of talonid) ; (1) Low (Sen \& Heintz, 1979)

116- *Lower molars, height of trigonid/talonid in lateral view : (0) Trigonid > talonid ; (1) Trigonid $\approx$ trigonid (Radulesco \& Sudre 1985)

117-*Lower molars, cristid oblique : (0) Mesio-disto-lingually oriented ; (1) Mesiodistally centered (Sen \& Heintz 1979) 
118-*Lower molars, paralophid development : (0) Weak ; (1) Well developed (McKenna \& Manning 1977 ; Radulesco \& Sudre 1985 ; Radulesco \& Samson 1987)

119- *Lower molars, paralophid orientation : (0) Transversal ; (1) Sagittal (McKenna \& Manning 1977 ; Radulesco \& Sudre 1985 ; Radulesco \& Samson 1987)

120-Relative size of low molars : (0) $\mathrm{m} 3 \geq \mathrm{m} 2$; (1) $\mathrm{m} 3<\mathrm{m} 2$; (2) Size obviously increasing from $\mathrm{m} 1$ to $\mathrm{m} 3$ (char. 86 in Gheerbrant et al. 2005)

121-Lower molars, postentoconulid : (0) Absent ; (1) Present (char. 82-83-84 modified after Gheerbrant et al. 2005)

122-Lower molars, lophodonty : (0) Bunodont-lophodont structure ; (1) True lophodonty (char. 126 modified after Gheerbrant et al. 2005)

123-Lower molars, labial cingulid : (0) Present ; (1) Absent (char. 68 modified after Gheerbrant et al. 2005)

124-Lower molars, lingual cingulid : (0) Present ; (1) Absent (Sen \& Heintz 1979)

125-m1-2, trigonid/talonid volume in occlusal view : (0) Trigonid $\geq$ talonid ; (1) Trigonid $<$ talonid (Sen \& Heintz 1979 ; char. 75 modified after Gheerbrant et al. 2005)

126-*m1-2, hypoconulid : (0) Present ; (1) Absent

127-m1-2, hypoconulid position : (0) Hypoconulid median ; (1) Hypoconulid labial (char. 81 modified after Gheerbrant et al. 2005)

128-m3, hypoconulid : (0) Strong ; (1) Weak (char. 98 in Froehlich 2002)

129-*m3, hypoconulid connection (o) : (0) Hypoconulid possess at least two crests reaching the distal flank of entoconid ; (1) Only one crest reaches the distal flank of entoconid ; (2) Isolated (with or without crests)

130-*m3, hypoconulid (inclination) in lingual view : (0) Hypoconulid parallel to the entoconid ; (1) Hypoconulid distally inclined (Sen \& Heintz 1979) 


\section{APPENDIX S2. DATA MATRIX OF 130 CHARACTERS (10 CRANIAL- MANDIBULAR, 120 DENTAL) APPLIED ON 14 TERMINAL TAXA (PERISSODACTYLS, HYRACOID, PROBOSCIDEANS, EMBRITHOPODS, AND PHENACOLOPHUS). THE THREE OUTGROUPS ARE $A$ PRIORI XENICOHIPPUS, ARENAHIPPUS, AND RADINSKYA}

Taxon
Xenicohippus
Arenahippus
Radinskya
Seggeurius amourensis
Eritherium azzouzorum
Phosphatherium escuilliei
Phenacolophus fallax
Palaeoamasia kansui
Hypsamasia seni
Crivadiatherium mackennai
Crivadiatherium iliescui
Arsinoitherium zitteli
Arsinoitherium giganteum
Namatherium blackcrowense

Taxon

Xenicohippus

Arenahippus

Radinskya

Seggeurius amourensis

Eritherium azzouzorum

Phosphatherium escuilliei

Phenacolophus fallax

Palaeoamasia kansui

Hypsamasia seni

Crivadiatherium mackennai Crivadiatherium iliescui Arsinoitherium zitteli Arsinoitherium giganteum Namatherium blackcrowense
$0000000001 \quad 11111111122222222223 \quad 3333333334 \quad 4444444445 \quad 5555555556 \quad 6666666667$ $\begin{array}{llllllll}1234567890 & 1234567890 & 1234567890 & 1234567890 & 1234567890 & 1234567890 & 1234567890\end{array}$

$020010000101000000 ? 0011110000011101000001 ? 100100001000-000000000110111$ 1 1?00100011 00????00?2 1?1??00000 11101??000 1??00?0101 1000-00??0 0?00?00011 ??0????000 0???????? ???????0?? ???????00? ??0?0??001 1?00-00?01 0?0110?011 ?????00?? 000010-1?0 0?01000?11 110011???? 0?10120000 1021111?10 001--10?11 12?00?0?10 000?11--?? ?????10111 00-01??111 0?0010011- -011011010 1101110011 $12100010100101 ? ?--? 01 ? 10 ? 1011101000--1111$ ? $0010011--0110110111101110112$ ?2?0?110?? 11?100-??2 ???00110?? -100--?1?? ??10020001 0021100110 1100001100 00?0?0?0?0 $1000011101011000011111100111101010011000003111012-1001001100$ ?????????? $10000111 ? 100111001011110000110$ ??0????000 0031110?2- 1001001???

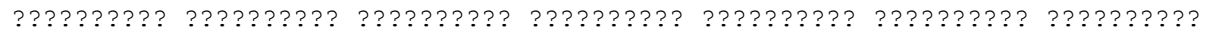
???????? ????????? ???????? ???????? ???????? ? ??????? ???????? $0001110100100011-110001100001101110--111$ 11110-1000 01-111102- 101--01100 ?1??????? 1???????? ????????? ???????? ??110-??? ????????- ?01--01100 121??????1 101000--0? ?????00011 01100--111 1?10020000 $003111002-101--00100$

$0000000000 \quad 0000000000 \quad 0000000001 \quad 1111111111 \quad 1111111111 \quad 1111111111$ $\begin{array}{llllll}777777778 & 8888888889 & 9999999990 & 0000000001 & 1111111112 & 2222222223\end{array}$ $\begin{array}{llllllll}1234567890 & 1234567890 & 1234567890 & 1234567890 & 1234567890 & 1234567890\end{array}$ 10010??110 01000110111111010010000002100110011000000001000011 ??010??010 0????11100 00?00????0 ????12?0?1 100110?000 ?0??1??01? -?0?????? ????????? ???????? ????????? ????????1 ????????? 0?0????100 1??110?00? 00?????000 ?001?21011 1011100002 ?001000011 00011100011001110101 ?011??1100 $000113011110111 ? 10011011101011$ 000111-?11 -0011--101 -010?-1100 $0001130101 \quad 11211010 ? 21111101021$ 01001110000000110100 ?0000?0011 0001120010 0120100002 000111-1-021?????10 $11011110111111001111 \quad 1011001001 \quad 1120000002011101-121$ ??1?????? ????????? ???????? ????????? ???????? ?????????

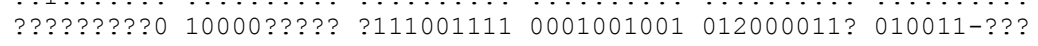
???1110??0 10000??011 $111101111100010010010120000110011111-000$ $10101000001011110001001111111111-00110011120110000011101-12 ?$ 1?1??????0 10101???01 ?0??????11 11-0011001 1120110000 011?01-??? 111 ?????? ????????? ???????? ??? ?0??? ???????? ???????? 


\section{APPENDIX S3. TABLE OF MEAN SIZE VALUES OF STUDIED TAXA}

N.B. The measurements are given in $\mathrm{mm}$. The talonid width is taken into consideration when trigonid is not accurate. $\mathrm{N}$, numbers of specimens measured; L, length; $\mathrm{W}$, width; $\mathrm{P} / \mathrm{p}$ and M/m are upper/lower premolars and molars, respectively; '-', specimen not available; '?', measurements not accurate due to possible damage or advanced wear stage. For the length/width diagrams related to that table, see Figure 4 in the main text. The premolars and molars of Crivadiatherium, Hypsamasia and the new material of P. kansui were directly measured by authors. Other measurements are from McKenna \& Manning (1977), Sen \& Heintz (1979), Kaya (1995), A. Gül, unpub. data (2003), Sanders et al. (2004, 2014), Pickford et al. (2008).

\begin{tabular}{|c|c|c|c|c|c|c|c|c|c|c|c|c|}
\hline & $(\mathrm{N})$ & $\begin{array}{c}\mathrm{P} 2 \\
\mathrm{~L} / \mathrm{W}\end{array}$ & $(\mathrm{N})$ & $\begin{array}{c}\mathrm{P} 3 \\
\mathrm{~L} / \mathrm{W}\end{array}$ & $(\mathrm{N})$ & $\begin{array}{c}\mathrm{P} 4 \\
\mathrm{~L} / \mathrm{W}\end{array}$ & $(\mathrm{N})$ & $\begin{array}{c}\text { M1 } \\
\mathrm{L} / \mathrm{W}\end{array}$ & $(\mathrm{N})$ & $\begin{array}{c}\mathrm{M} 2 \\
\mathrm{~L} / \mathrm{W}\end{array}$ & $(\mathrm{N})$ & $\begin{array}{c}\mathrm{M} 3 \\
\mathrm{~L} / \mathrm{W}\end{array}$ \\
\hline Hypsamasia & 1 & $? / 17$ & 1 & $18 / ?$ & & - & & - & 1 & $? / 39.9$ & & - \\
\hline \multicolumn{13}{|l|}{ P. kansui } \\
\hline (1) Eski-Çeltek & & - & 1 & $? / 18.4$ & 3 & $19.3 / 23.3$ & 3 & $27.0 / 29.4$ & 4 & $31.1 / 30.5$ & $4 / 3$ & $31.8 / 33.5$ \\
\hline (2) Orhaniye & 2 & $19.6 / 16.3$ & 2 & $18.0 / 22.3$ & 2 & $19.5 / 26.1$ & 2 & $26.9 / 29.4$ & 2 & $36.3 / 32.2$ & $2 / 1$ & $40.0 / 37.2$ \\
\hline (3) Boyabat & & - & & - & & - & & - & & - & & - \\
\hline (4) Cicekdag & & - & & - & & - & & - & & - & & - \\
\hline (5) Bultu-Zile & & - & & - & & - & & - & & - & & - \\
\hline $\begin{array}{l}\text { P. kansui } \\
\text { (present study) }\end{array}$ & 1 & $14.7 / 16.5$ & 1 & $16.2 / 18.7$ & 1 & $? / 24.5$ & 1 & $23.8 / 30.4$ & 1 & $32.0 / 33.2$ & 1 & $33.5 / 28.1$ \\
\hline BOY-2 & & - & & - & & - & & - & 1 & $29.1 / 30.0$ & 1 & $30.0 / 32.0$ \\
\hline C. mackennai & & - & & - & & - & & - & & - & & - \\
\hline C. iliescui & & - & & - & & - & & - & & - & & \\
\hline Namatherium & & - & 1 & $17.0 / 24.4$ & 1 & $19.0 / 26.1$ & 2 & $27.7 / 29.1$ & 2 & $37.7 / 37.5$ & 2 & $40.8 / 40.7$ \\
\hline A. zitteli & 2 & $26.2 / 26.4$ & 3 & $29.2 / 32.9$ & 2 & $30.10 / 37.0$ & 1 & $52.5 / 48.6$ & 1 & $70.5 / 57.4$ & 1 & $60.5 / 55.0$ \\
\hline A. giganteum & & - & 1 & $36.0 / ?$ & 3 & $42.0 / 42.9$ & & - & 2 & $76.5 / 61.0$ & 2 & $71.8 / 61.2$ \\
\hline Ph. fallax & 1 & $5.7 / 5.4$ & 1 & $6.1 / 5.1$ & 1 & $11.4 / 9.6$ & & $?$ & & $?$ & & $?$ \\
\hline
\end{tabular}

\section{Hypsamasia}
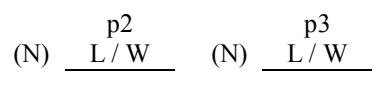

(N) \begin{tabular}{c}
$\mathrm{p} 4$ \\
$\mathrm{~L} / \mathrm{W}$ \\
\hline
\end{tabular}

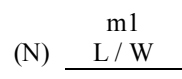

(N) $\quad \mathrm{m} 2$

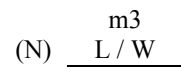

(1) Eski-Çeltek

(2) Orhaniye

(3) Boyabat

(4) Cicekdag

(5) Bultu-Zile

P. kansui

(this study)

BOY-2

C. mackennai

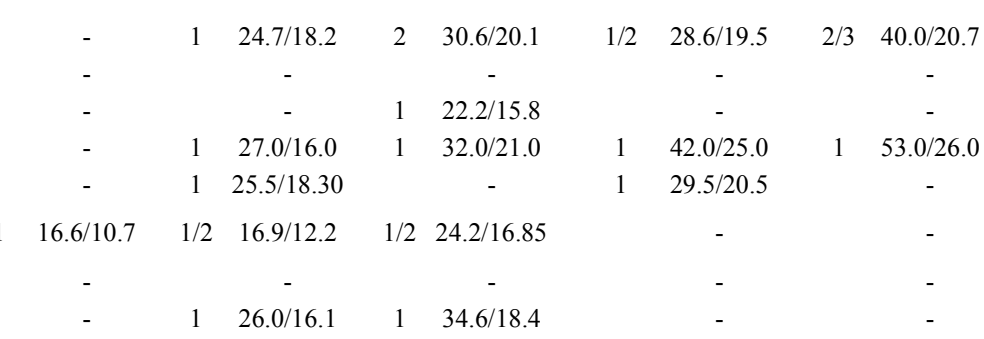


1

2

3

4

5

6

7

8

9

10

11

12

13

14

15

16

17

18

19

20

21

22

23

24

25

26

27

28

29

30

31

32

33

34

35

36

37

38

39

40

41

42

43

44

45

46

47

48

49

50

51

52

53

54

55

56

57

58

59

60

\begin{tabular}{|c|c|c|c|c|c|c|c|c|c|c|c|c|}
\hline C. iliescui & 1 & $? / 16.1$ & 1 & $25.3 / 18.0$ & 1 & $28.0 / 18.5$ & & - & 2 & $46.35 / 26.05$ & 2 & $56.5 / 25.85$ \\
\hline Namatherium & & - & & - & & - & & - & & - & & - \\
\hline A. zitteli & $3 / 1$ & $25.9 / 17.3$ & $4 / 2$ & $28.2 / 22.3$ & $4 / 2$ & $32.4 / 26.2$ & $11 / 4$ & $48.8 / 36.1$ & $13 / 10$ & $61.9 / 43.4$ & $8 / 9$ & $59.3 / 44.5$ \\
\hline A. giganteum & $1 / 2$ & $31.2 / 27.4$ & 2 & $31.2 / 31.0$ & $3 / 2$ & $38.6 / 33.0$ & 1 & $53.4 / 49.3$ & $3 / 2$ & $88.3 / 58.9$ & 1 & $81.6 / 58.6$ \\
\hline Ph. fallax & 1 & $7.7 / 5.1$ & 1 & $9.7 / 5.9$ & 1 & $12.1 / 6.4$ & 1 & $12.4 / 8.2$ & 2 & $13.2 / 8.9$ & 2 & $15.8 / 9.3$ \\
\hline
\end{tabular}




\title{
APPENDIX S4. CHARACTER DISTRIBUTION OF THE STRICT CONSENSUS TREE
}

\author{
N.B. For the strict consensus tree, see main text Figure5. For some annotations, Antoine \\ (2002) and Gheerbrant et al. (2005) are followed. Unambiguous and nonhomoplastic \\ characters are in bold, unambiguous characters displaying an autapomorphy where character \\ state is not homoplastic are in italic, unambiguous and weakly homoplastic characters $(0.75 \leq$ \\ $\mathrm{RI}<1)$ are underlined and character state is in brackets. Unambiguous and strongly \\ homoplastic characters $(\mathrm{RI}<0.75)$ lack any of annotations above, except the character state in \\ brackets. Ambiguous characters are accompanied by an asterisk, related nodes which \\ probably cause the ambiguity mentioned in square brackets and character state indicated in \\ brackets as ': (Character state)' only if it is different from the concerning main node.
}

\begin{abstract}
Node 1 $\rightarrow$ Arenahippus : 9*(1)[node 3 or 4], 20*(2)[node 5-Ph. fallax], 21*(1)[node 4 or 4Phosphatherium], 48*(1)[node 16-15], 90*(0)[node 21-Ph. fallax], 94*(0)[node 4-Eritherium and node 6 or 7]; Node 1 $\rightarrow$ Radinskya : 43*(0)[node 4, node 9-H. seni], 60*(1)[node 4Phosphatherium], 120*(1)[node 4-Eritherium:(1), node 9-P. kansui:(2) and node 4:(2), node 6:(0) or node 3:(2), node 5-Ph. fallax:(2)] ; Node 2 (Paenungulata) : 18(1), 29(1), 30(1), 38(1), 39(1), 40(1), 53(1 or 2), 54(1), 59(1), 75(1), 79(0), 87(0); Node 3 (Proboscidea + Seggeurius) : $15^{*}(1)$ [node 8 or node $8-A$. zitteli], 45(1), 57*(1)[ node 8-A. zitteli], 66*(1)[node 0Xenicohippus], 84*(1)[ node 8-A. zitteli, node 9-P. kansui], 99(0); Seggeurius amourensis : 23(0), 63*(1)[node 6:(1), node 9:(0) or node 6-N. blackcrowense:(1), node 8], 78*(1)[node 0Xenicohippus], 86(0), 125*(0)[node 8, node 9-P. kansui] ; Node 4 (Proboscidea) : 26*(1)[node 5- Ph. fallax], 43*(0)[node 1-Radinskya, node 9-H. seni], 46(0), 48*(1)[node 1-Arenahippus], 49(1), 55(0), 62*(1)[node 5-Ph. fallax], 80(1), 98*(1)[node 6 or node 7], 106(3), 107*(0)[node 5-Ph. fallax], 108(1), 117(1), 123*(1)[node 9-C. mackennai and node 6 or node 7], 127(1); Eritherium azzouzorum : 32(0), 120*(1)[node 1-Radinskya, node 9-P. kansui:(2) and node 2:(2), node 6:(0) or node 3:(2), node 5-Ph. fallax:(2)] ; Phosphatherium escuilliei : $7 *$ (1)[node 5-Ph. fallax], 12*(1)[ node 5-Ph. fallax], 35*(0)[node 5 or node 6], 60*(1)[node 1-Radinskya], 70(2), 79*(1)[node 9 or node $9-P$. kansui], 112*(1)[node 5], 122*(1)[node 5], 129*(2)[node 9-C. iliescui:(0) and node 5, or node 8-A. zitteli, node 9-P. kansui]. Node 5 (Embrithopoda sensu lato) : 11(1), 51(0), 65(0), 69(0), 70(0), 72(1), 112*(1)[node 4-Phosphatherium], 114(0), 122*(1)[node 4-Phosphatherium], 126(1), 128(1) ; Phenacolophus fallax : 7*(1)[node 4Phosphatherium], 12*(1)[node 4-Phosphatherium], 14*(1)[node 4 or node 4-Phosphatherium], 20*(2)[node 1-Arenahippus], 24*(0)[node 9-P. kansui and node 4 or node 4-Phosphatherium], 26*(1)[node 4], 27(1), 58*(1)[node 9 or node 9-P. kansui], 62*(1)[node 4], 77(1), 90*(0)[node 1-Arenahippus], 93(0), 107*(0)[node 4], 110(0); Node 6 (Embrithopoda sensu stricto) : 53(3), 59(2), 73(1), 105*(0)[node 0-Xenicohippus] ; Namatherium blackcrowense : 13(1); Node 7
\end{abstract}


(Arsinoitheriidae) : $1 *(0), 2(0$ or 1$), 16^{*}(1)$ [node 4 or node 4 -Eritherium], 28*(1)[node 3 or node 4], 33*(1), 47(1) ; Node 8 (Arsinoitheriinae) : 44(1), 83(1), 101*(1)[node 9-P. kansui], 102(1), 104*(0)[node 0-Xenicohippus], 116(1), 125*(0)[node 3-Seggeurius, node 9-P. kansui]; Arsinoitherium zitteli: 4*(1)[node 8], 8*(1)[node 8], 19*(1)[node 8], 34*(1)[node 8], 42*(1)[node 8], 52*(1)[node 8], 76*(0)[node 8], 84*(1)[node 3, node 9-P. kansui], 95*(1)[node 8]; Arsinoitherium giganteum : $2 *(1)$ [node 7]; Node 9 (Palaeoamasiinae) : 20(1), 31*(1)[node 2:(0), node 3-Seggeurius:(1) or node 4:(0), node 5:(0)], 40*(0), 89*(1)[node 0-Xenicohippus], 91*(1)[node 0-Xenicohippus], 92*(1)[node 0-Xenicohippus], 106(0), 115(0); Palaeoamasia kansui : 24*(0)[node 5-Phenacolophus and node 4 or node 4-Phosphatherium], 37(1), $82 *(1)$ [node 0-Xenicohippus], 84*(1)[node 3, node 8-A. zitteli], 101*(1)[node 8], 103(1), 125*(0)[node 3-Seggeurius, node 8]; Hypsamasia seni: 25*(1)[node 0-Xenicohippus], $29 *(0)[$ node 3:(1)], 43*(0)[node 1-Radinskya, node 4]; Crivadiatherium mackennai : $123^{*}(0)$ [node $6:(1)$ or node 7:(1)], 124(0); Crivadiatherium iliescui : 128*(0)[node 5:(1)], $129(0), 130(0)$. 